\title{
ASSESSING THE 'CHOOSINESS' OF JOB SEEKERS. AN EXPLORATORY APPROACH AND EVIDENCE FOR \\ ITALY
}

\author{
UGO TRIVELLATO \\ ANNA GIRALDO
}

CESIFo Working PaPer No. 925

CATEGORY 4: LABOUR MARKETS

APRIL 2003

\footnotetext{
An electronic version of the paper may be downloaded

- from the SSRN website: www.SSRN.com

- from the CESifo website: www.CESifo.de
} 


\title{
ASSESSING THE 'CHOOSINESS' OF JOB SEEKERS. AN EXPLORATORY APPROACH AND EVIDENCE FOR ITALY
}

\begin{abstract}
We use data about job search and work preferences, typically collected in a Labour Force Survey, in order to construct an indicator of .choosiness. of the supply of job-seekers. The method for obtaining the indicator, first at individual level and then at aggregate levels, is based on results from multiple correspondence analysis. We investigate the informational value of the indicator by examining its stability over time and its predictive power on labour force transitions. Empirical analyses of cross-section and panel samples of jobseekers from the Italian quarterly Labour Force Survey clarify the potentials (and limitations) of the approach.
\end{abstract}

JEL Code: C42, J22, J64.

Keywords: job search, multiple correspondence analysis, survey data, unemployment.

Ugo Trivellato

Dipartimento di Scienze Statistiche

Università di Padova

Via Cesare Battisti, 241

35121 Padova

Italy

trivell@stat.unipd.it

\author{
Anna Giraldo \\ Dipartimento di Scienze Statistiche \\ Università di Padova \\ Via Cesare Battisti, 241 \\ 35121 Padova \\ Italy
}

Research for this paper was supported by a grant from the Italian Ministry of Education, University and Research to the project „Dynamics and inertia in the Italian labour market and policy evaluation.“ U. Trivellato acknowledges support from the CES, University of Munich, while visiting the Center in March 2003. Individual anonymised data from the Italian Labour Force Survey were kindly provided by Istat (the Italian statistical agency), under a research agreement with the Department of Statistics, University of Padova. Earlier drafts were presented at a Workshop in Brixen (Bozen), 11-12 February 2000, and at the 17th AIEL Conference, Salerno, 27-27 September 2002. We are grateful to Giorgio Brunello, Gianpiero Dalla Zuanna, Pietro Gennari, Wim Leunis, Lia Pacelli, Paolo Sestito, Enrico Rettore, Giuseppe Tattara, Nicola Torelli and Niels Westegård-Nielsen for useful comments and suggestions. The usual disclaimer applies. 


\section{Introduction}

The dominant trait of current procedures for measuring unemployment, and, broadly, labour force participation, is emphasis on the conventional guidelines recommended by the International Labour Office in general terms (ILO, 1983; Hussmans, Merhan and Verma, 1990) and made operational by national statistical agencies to fit specific country contexts (see, e.g., Sorrentino, 2000). Essentially, the definition of unemployment is based on three criteria to be satisfied simultaneously. People above a specific age are considered unemployed if, during the reference period - generally one week, they were (i) without work, (ii) currently available for work, and (iii) actively seeking work.

While this measurement strategy is deemed to be reasonably satisfactory for purposes of consistent comparisons across space and over time, it does suffer from definite limitations. Some of the basic difficulties depend on the fact that it is much harder to measure "the hole [of unemployment] rather than the doughnut [of employment]", as Shiskin (1976) pointed out now more than twenty-five years ago. Recent trends in the economies of developed countries have stressed these difficulties. The spectrum of situations in the labour market has become more diversified, and situations to the boundaries between the usual labour force states have expanded 1 .

Various approaches have been proposed to deal with the issue ${ }^{2}$. First, one can take the "building block approach" suggested by ILO (1980). 3 . aggregates of interest are evaluated by adding to or removing from a reference aggregate particular sub-sets of people, according to variations in definitions ${ }^{4}$. A second method centres on the salience of the distinction among labour force states, which is assessed by looking at the similarities or differences among the various groups in terms of their probability of transition to employment (Flinn \& Heckman, 1983; Jones \& Riddell, 1999). A third route consists of complementing current measures of unemployment with investigations on the informational value of job search data - job search methods, intensity, etc. - and on the impact of job search behaviour on the probability of subsequent employment (see, e.g., Osberg, 1993; Micklewright \& Nagy, 1999; Böheim \& Taylor, 2001).

This paper takes a route similar to the last one, and has a definite aim: to construct an indicator of 'choosiness' of the supply of job-seekers, moving from the set of questions about job search and work preferences typically included in a Labour Force Survey (LFS).

In LFSs, it is common practice to add to the questions on job search strictly required for identifying the unemployed further questions on the conditions of labour supply: willingness to move; availability with respect to temporary or atypical jobs; minimum acceptable wage; etc.. Our purpose is to exploit the set of questions about search/availability/preferences for work, in order to

\footnotetext{
${ }^{1}$ For a discussion of some 'grey areas' between employment, unemployment and inactivity, relevant for analytical and policy purposes, see Malinvaud (1986), who considers four somewhat ambiguous domains: visible under-employment, training-employment, pre-retirement, and discouraged workers.

${ }^{2}$ We refer here to approaches which apply to micro-data on individuals, and are essentially classificatory or at most involve some reduced-form modelling.

${ }^{3}$ Indeed, the suggestion of a set of alternative unemployment indicators, known as the U-1 to U-7 framework, goes back to Shiskin (1976). It is still in use at the US Bureau of Labor Statistics.

${ }^{4}$ An interesting case study applied to Italy is by Rossi (1997).
} 
build up indicators summarizing information on the choosiness of job-seekers, at various levels of aggregation - from individual level up to the entire group of job-seekers 5 .

It should be emphasized at the outset that the degree of choosiness of the labour supply of job-seekers is not observable, and that available proxies are often endogenous to the labour market (dis)equilibrium process to be explained. Thus, our contribution must be viewed as an exploratory exercise for obtaining descriptive indicators of choosiness. Our method relies on results from Multiple Correspondence Analysis (MCA), and is presented and discussed in some detail. Empirical analyses on cross-section and panel samples of job-seekers from the Italian quarterly Labour Force Survey (ILFS) help to clarify the main points, and the potentials and limitations of the approach.

The rest of the paper is organized as follows. First, we describe the data used and motivate the choice for MCA (Section 2). Then we focus on the basic, preliminary issue: does the pattern of the data on search/availability/preferences for work suggest that there is a factor which may be sensibly interpreted in terms of choosiness of job-seekers? The evidence is positive (Section 3). Based on that, we present the method for obtaining the indicator of choosiness, first at individual level and then at aggregate levels (Section 4). We proceed to investigate the informational value of the indicator, by examining its stability over time and its predictive power on labour force transitions. The measurement properties of the indicator, as assessed by its profile over the panels, turn out to be quite satisfactory. As regards gross flows from unemployment, results include some seemingly striking findings - among unemployed, the less choosy have a probability of transition to employment lower than the more choosy ones. A sensible way of rationalizing these findings is to point to unobserved heterogeneity and, chiefly, to endogeneity (Section 5). Finally, we present and briefly comment selected results for Italy. We conclude with some suggestions for using the indicator properly for comparisons across space and over time (Section 6).

\section{Data and methods}

For all persons who state that they are seeking work, the questionnaire of the ILFS includes a series of questions dealing with: (i) intensity of job search (number and type of search actions); (ii) immediate availability for work; (iii) availability or preferences with respect to type of job, working time regime, and place of work; (iv) minimum acceptable wage (conditional on the preferences given above); (v) ongoing duration of search; (vi) registration at the Labour Exchange Office; (vii) recipiency of unemployment insurance or benefits.

We derived ten variables from these questions. They are described in Table 1, which is selfexplanatory. Categorization of the variables entailed some subjective judgements - obviously, except for the case when the variables were originally dichotomous. The guideline was to choose a small number of categories for each variable, in order to give them a well-balanced role in accounting for the variance in multiple correspondence analysis. Note also that, within each variable, the ordering of categories was taken to be consistent with a (presumed) increasing degree of choosiness.

Some clarifications are immediately in order, to motivate the choice to use multiple correspondence analysis in building up a summary indicator of choosiness. First of all, it is worth noting that, in our opinion, it would be improper to use just the question on minimum net monthly wage. Indeed, prima facie it might appear that answers to this question can be taken as a proxy for the reservation wage: a straight, theory-based indicator of choosiness. Unfortunately, this is not the case. The question on minimum net monthly wage is conditional upon the set of questions on availability/preferences with respect to type of job, working time regime, and place of work: therefore, answers to it cannot be interpreted as the reservation wage. What is more, the format of

\footnotetext{
${ }^{5}$ Note that this line of attack has some clear analogies with efforts made at the OECD, in the context of cross-country comparisons, to produce summary indicators of employment protection legislation and product market regulation. See Grubb \& Wells (1993), OECD (1994) and Nicoletti, Scarpetta \& Boylaud (1999).
} 
Table 1: Variables used and their categorization for multiple correspondence analysis

\begin{tabular}{|c|c|}
\hline Codes & $\begin{array}{l}\text { Variables considered for multiple correspondence analysis (i.e., questions from } \\
\text { ILFS questionnaire) and description of categories }\end{array}$ \\
\hline$\overline{T Y P}$ & Types of job search actions carried out within last 30 days $(Q .47)$ \\
\hline Typ1 & Otherwise \\
\hline Typ2 & Only for a job as employee in private sector \\
\hline$\overline{A V A}$ & "Would you be immediately available for work?" (Q. 50) \\
\hline Aval & Yes, in any conditions \\
\hline Ava2 & Yes, in adequate conditions \\
\hline Ava3 & No \\
\hline$\overline{J O B}$ & "What type of job you are mainly looking for?"(Q.51) \\
\hline Job1 & Otherwise \\
\hline Job2 & As employee with a long-term contract \\
\hline$\overline{T I M}$ & "At what working time regime would you be willing to work?" (Q. 52) \\
\hline Tim 1 & Any working time \\
\hline $\operatorname{Tim} 2$ & Preferably full-time or preferably part-time \\
\hline Tim3 & Only full-time or only part-time \\
\hline$\overline{P L A}$ & "Where would you be willing to work?"(Q. 53) \\
\hline Pla1 & Otherwise \\
\hline Pla2 & In town of residence or any other town within daily commuting distance \\
\hline$\overline{W A G}$ & $\begin{array}{l}\text { "What is the minimum net monthly wage at which you would be willing to work, } \\
\text { given the type of job, working time and place of work indicated above?" }(Q .54)\end{array}$ \\
\hline Wag1 & Net monthly wages less than It. Lire $1,500,000$ (Euro 775) \\
\hline Wag2 & Net monthly wage between $1,500,000$ and $1,700,000$ It. Lire (Euro $775-878$ ) \\
\hline Wag3 & Net monthly wage no less than It. Lire 1,700,000 (Euro 878) \\
\hline$R E G$ & "Are you registered at the Labour Exchange Office?" (Q. 56) \\
\hline Reg1 & Yes \\
\hline Reg2 & No \\
\hline$\overline{D U R}$ & "How long have you been looking for a job?"(Q.46) \\
\hline Dur1 & 0-11 months \\
\hline Dur2 & $12-23$ months \\
\hline Dur3 & 24 months or more \\
\hline NUM & Number of job search actions carried out within last 30 days (from Q. 47) \\
\hline Num1 & More than 1 \\
\hline Num2 & 1 \\
\hline$\overline{B E N}$ & "Do you receive unemployment insurance or benefits?" (Q. 58) \\
\hline Ben 1 & Yes \\
\hline Ben2 & No \\
\hline
\end{tabular}


the question - open answer, with no precise reference to the number of hours of work (and other working arrangements) - is definitely far from the stringent prescriptions of contingent valuation to assess appropriately the economic value of non-market goods - in our case, leisure (Hausman, 1993; Bateman \& Wallis, 1995) 7 .

In broader terms, we should also consider that household survey data are affected by several sources of non-response and imprecision, which result in sizeable measurement errors (see Bound, Brown \& Mathiowetz, 2001, for a comprehensive review). Furthermore, measurement errors are likely to be higher for questions that are not the core ones of a survey. In LFSs, this is precisely the case for questions about search/availability/preferences for work not required to identify the

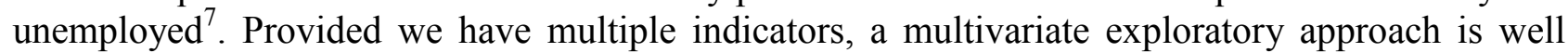
suited to deal with such imprecise information.

Lastly, we must explain the reason for choosing MCA, as opposed to the alternative approach based on factor analysis, adopted, for example, by Nicoletti, Scarpetta \& Boylau (1999) for constructing the OECD's summary indicators of labour market regulation. The reason is straightforward: MCA does not require a continuous metric for observed variables. Thus, it is consistent with the scale of available information, which is in fact qualitative: it saves us from carrying out a questionable transformation of variables and provides us with robust findings.

As for the data sets for empirical analyses, they consist of three cross-section samples from the 1997.IV, 1998.I and 1998.IV survey occasions of the ILFS, and of two two-wave panels constructed from them - 1997.IV-1988.I and 1997.IV-1998.IV 8 .

The three cross-section samples are made up of persons who reported they were looking for a job and actively seeking work - in the sense that they had taken at least one step to seek work within the previous 30 days. We will call them simply 'job-seekers'. They consist of 11-12,000 individuals.

The two panels consist of persons who were continugus job-seekers. They were extracted from the overall 1997.IV-1998.I and 1997.IV-1998.IV panels ${ }^{9}$ respectively, and contain individuals who reported that they were (i) job-seekers on both survey occasions and (ii) continuously looking for a job during the period separating them - three months and twelve months respectively 10 . The rationale for this choice was to have a data set suitable for stability analysis, i.e., for assessing the consistency of the measures of interest - the individual indicator of choosiness and the survey variables used to construct it - over the same persons, experiencing roughly the same labour force condition, on two subsequent survey occasions. Patently, when interpreting the results, we must take into account the fact that the panels are affected by a selection process, shaped by the very same condition of having been continuously looking for a job: the longer the interval between survey occasions, the stronger the selection. The 1997.IV-1998.I panel - or 'quarterly panel', as we also call it - comprises 3,223 job-seekers, whereas the 1997.IV-1998.IV panel - or 'yearly panel' is reduced to 1,592 individuals 11 .

\footnotetext{
${ }^{6}$ For attempts at estimating the reservation wage from IFLS data via a modelling approach, see Mazzotta (1998) and Boeri \& Garibaldi (2000). Precisely due to the methodological weaknesses of the survey instrument, we find these attempts problematic and their results dubious.

${ }^{7}$ These questions may be perceived as secondary, and handled more loosely, by interviewers and also by respondents.

${ }^{8}$ The ILFS is a quarterly survey with a 2-2-2 rotating panel design (see, e.g., Trivellato, 1997).

${ }^{9}$ Panels were obtained using the record linkage procedure by Paggiaro \& Torelli (2000).

${ }^{10}$ Operationally, we assessed the latter condition mainly on the basis of the answers to the question on duration of search. For the 1997.IV-1998.I panel, on the second occasion job-seekers had to report a duration of search $\geq 3$ months. In the 1997.IV-1998.IV panel, on the 1998.IV occasion job-seekers had to report a duration of search $\geq 12$ months; besides, they had to have reported that they were job-seekers at the intermediate survey occasion at which they were also interviewed (given the design of the ILFS, 1998.I for roughly half the panel and 1998.III for the remaining half).

${ }^{11}$ Given the 2-2-2 rotating panel design of the ILFS, in the absence of the condition of continuous job search, one would have expected the quarterly and yearly panels to be roughly of the same size, i.e., $50 \%$ of the initial cross-section sample (apart from attrition, arguably stronger for the yearly panel).
} 
Descriptive statistics are given in Table 2. Let us look first at the data on cross-section samples. The large majority of job seekers, $81 \%$ or more, are unemployed - more precisely, 31$33 \%$ are unemployed job losers, 34\% are seeking their first job, and 15-16\% are "others seeking a job, $12,16-17 \%$ are employed but seeking a different job; $1-2 \%$ are persons classified as out of the labour force. Of the panel samples, the number of people continuously unemployed grows appreciably, to $85 \%$ for the quarterly panel and to $89 \%$ for the yearly panel - the increase being concentrated on first job seekers (up to $47 \%$ in the yearly panel), contrasted by a decrease in the number of job losers (down to $29 \%$ in the yearly panel). Employed job-seekers drop to $14 \%$ and $10 \%$ respectively, and persons not in the labour force stay around $1 \%$.

The distribution of job-seekers by the ten variables on search/availability/preferences for work is given in Table $3^{13}$. Of these variables, it is important to remark that just seven are used in final multiple correspondence analysis. Three variables were discarded, either because of their ambiguous meaning with respect to the latent dimension of interest - choosiness - or because their empirical distribution was too highly polarized, thus precluded meaningful use in the context of MCA ${ }^{14}$. The variables discarded were:

(a) DUR, i.e., the variable resulting from the question "How long have you been looking for a job?". This variable has a particularly dubious relationship with choosiness: coeteris paribus, one would expect the more choosy job-seekers to search longer; on the other hand, coeteris paribus, one would also expect that the longer the ongoing duration of a spell of job search, the lower the choosiness. Indeed, $D U R$ is essentially endogenous to the search process.

(b) NUM, i.e., the variable "Number of job search actions carried out within the last 30 days". The meaning of this variable too is ambiguous. In addition, it has answers heavily concentrated on a small number of types of actions.

(c) BEN, i.e., the variable associated with the question "Do you receive unemployment insurance or benefits?". This exclusion is seemingly incongruous, given the well-established importance of unemployment benefits in influencing job search behaviour in developed economies. One should consider, however, that the variable is largely dominated by the answer no: a reflection of the limited role played by unemployment benefits within the Italian welfare system (Bertola et al., 2000) ${ }^{15}$. This is the main reason for discarding $B E N$ from the variables of multiple correspondence analysis.

\footnotetext{
12 These are individuals who, to an initial question about their labour force state did not identify themselves as unemployed, but from subsequent questions turned out to report seeking behaviour consistent with the definition of unemployment.

${ }^{13}$ There were some missing data to the question "What is the minimum net monthly wage at which you would be willing to work?": 238 (2.12\%) in 1997.IV, 236 (2.14\%) in 1998.I and 207 (1.73\%) in 1998.IV. A within-cell hot deck imputation was performed, based on the results of logit regressions. The predictors retained were: region of residence (North/Other); occupational status (Employed/Other); preferred working time regime (Only or preferably fulltime/Other); registration at the Labour Exchange Office (Yes/No).

${ }^{14}$ Results from a series of MCA, carried out on the entire set of ten variables and on various combinations of nine or eight of them, support the choice to restrict final correspondence analysis to the set of seven variables. Indeed, results do not vary appreciably when the set of variables involved is changed. As an example, for the 1997.IV sample, the portion of variance explained by the first factor ranges from $17.5 \%$ (with seven variables) to $12.9 \%$ (with ten variables), and the coordinates of the categories of the seven variables do not exhibit noticeable changes.

${ }^{15}$ For the period covered by our analyses, the only recipients of unemployment benefits were unemployed individuals with previous work experience: their replacement ratio was quite low, close to $30 \%$ of their previous pay. Unemployed individuals looking for their first job drew no benefits at all.
} 
Table 2: Job-seekers by gender and labour force state, 1997.IV, 1998.I, 1998.IV, panels 1997.IV1998.I and 1997.IV-1998.IV (samples)

\begin{tabular}{|c|c|c|c|c|c|c|c|c|c|}
\hline & & & Employed & $\begin{array}{l}\text { Unemployed } \\
\text { previously } \\
\text { employed }\end{array}$ & $\begin{array}{l}\text { Looking } \\
\text { for the } \\
\text { first job }\end{array}$ & $\begin{array}{l}\text { Others } \\
\text { seeking } \\
\text { a job }\end{array}$ & $\begin{array}{l}\text { Unemployed } \mathrm{N} \\
\text { total }\end{array}$ & $\begin{array}{l}\text { Not in the } \\
\text { labour } \\
\text { force }\end{array}$ & Total \\
\hline \multirow[t]{6}{*}{ 1997.IV } & Males & $\mathrm{N}$ & 1,034 & 2,061 & 1,863 & 232 & 4,156 & 84 & 5,274 \\
\hline & & $\%$ & 19.6 & 39.1 & 35.3 & 4.4 & 78.8 & 1.6 & 100.0 \\
\hline & Females & $\mathrm{N}$ & 793 & 1,539 & 2,002 & 1,504 & 5,045 & 107 & 5,945 \\
\hline & & $\%$ & 13.3 & 25.9 & 33.7 & 25.3 & 84.9 & 1.8 & 100.0 \\
\hline & Total & $\mathrm{N}$ & 1,827 & 3,600 & 3,865 & 1,736 & 9,201 & 191 & 11,129 \\
\hline & & $\%$ & 16.3 & 32.1 & 34.4 & 15.5 & 82.0 & 1.7 & 100.0 \\
\hline \multirow[t]{6}{*}{ 1998.I } & Males & $\mathrm{N}$ & 942 & 2,133 & 1,888 & 221 & 4,242 & 72 & 5,256 \\
\hline & & $\%$ & 17.9 & 40.6 & 35.9 & 4.2 & 80.7 & 1.4 & 100.0 \\
\hline & Females & $\mathrm{N}$ & 776 & 1,555 & 1,878 & 1,438 & 4,871 & 100 & 5,747 \\
\hline & & $\%$ & 13.5 & 27.1 & 32.7 & 25.0 & 84.8 & 1.7 & 100.0 \\
\hline & Total & $\mathrm{N}$ & 1,718 & 3,688 & 3,766 & 1,659 & 9,113 & 172 & 11,003 \\
\hline & & $\%$ & 15.6 & 33.5 & 34.2 & 15.1 & 82.8 & 1.6 & 100.0 \\
\hline \multirow[t]{6}{*}{ 1998.IV } & Males & $\mathrm{N}$ & 1,094 & 2,180 & 2,012 & 261 & 4,453 & 91 & 5,638 \\
\hline & & $\%$ & 19.4 & 38.7 & 35.7 & 4.6 & 79.0 & 1.6 & 100.0 \\
\hline & Females & $\mathrm{N}$ & 981 & 1,551 & 2,083 & 1,624 & 5,258 & 107 & 6,346 \\
\hline & & $\%$ & 15.5 & 24.4 & 32.8 & 25.6 & 82.8 & 1.7 & 100.0 \\
\hline & Total & $\mathrm{N}$ & 2,075 & 3,731 & 4,095 & 1,885 & 9,711 & 198 & 11,984 \\
\hline & & $\%$ & 17.3 & 31.1 & 34.2 & 15.7 & 81.0 & 1.7 & 100.0 \\
\hline \multirow{6}{*}{$\begin{array}{l}\text { Quarterly } \\
\text { panel* }\end{array}$} & Males & $\mathrm{N}$ & 240 & 597 & 587 & 60 & 1,244 & 15 & 1,499 \\
\hline & & $\%$ & 16.0 & 39.8 & 39.2 & 4.0 & 83.0 & 1.0 & 100.0 \\
\hline & Females & $\mathrm{N}$ & 196 & 465 & 670 & 369 & 1,504 & 24 & 1,724 \\
\hline & & $\%$ & 11.3 & 27.0 & 39.0 & 21.4 & 87.4 & 1.3 & 100.0 \\
\hline & Total & $\mathrm{N}$ & 436 & 1,062 & 1,257 & 429 & 2,748 & 39 & 3,223 \\
\hline & & $\%$ & 13.6 & 32.9 & 39.0 & 13.3 & 85.2 & 1.2 & 100.0 \\
\hline \multirow{6}{*}{$\begin{array}{l}\text { Yearly } \\
\text { panel** }\end{array}$} & Males & $\mathrm{N}$ & 86 & 273 & 374 & 21 & 668 & 4 & 758 \\
\hline & & $\%$ & 11.4 & 36.0 & 49.3 & 2.8 & 88.1 & 0.5 & 100.0 \\
\hline & Females & $\mathrm{N}$ & 70 & 192 & 370 & 189 & 751 & 13 & 834 \\
\hline & & $\%$ & 8.4 & 23.0 & 44.4 & 22.7 & 80.1 & 1.5 & 100.0 \\
\hline & Total & $\mathrm{N}$ & 156 & 465 & 744 & 210 & 1,419 & 17 & 1,592 \\
\hline & & $\%$ & 9.8 & 29.2 & 46.7 & 13.2 & 89.1 & 1.1 & 100.0 \\
\hline
\end{tabular}

* Job-seekers on both survey occasions and continuously looking for a job during the quarter separating them, from the 1997.IV-1998.I panel.

** Job-seekers on both survey occasions and continuously looking for a job during the year separating them, from the 1997.IV-1998.IV panel. 
Table 3: Distribution of job-seekers by variables used in multiple correspondence analysis, 1997.IV, 1998.I, 1998.IV, and panels 1998.IV-1998.I and 1997.IV-1998.IV

\begin{tabular}{|c|c|c|c|c|c|c|c|c|c|c|c|}
\hline \multirow{2}{*}{\multicolumn{2}{|c|}{ Variable }} & \multicolumn{2}{|c|}{ 1997.IV } & \multicolumn{2}{|c|}{ 1998.I } & \multicolumn{2}{|c|}{ 1998.IV } & \multicolumn{2}{|c|}{ Quarterly panel } & \multicolumn{2}{|c|}{ Yearly panel } \\
\hline & & $\mathrm{N}$ & $\%$ & $\mathrm{~N}$ & $\%$ & $\mathrm{~N}$ & $\%$ & $\mathrm{~N}$ & $\%$ & $\mathrm{~N}$ & $\%$ \\
\hline \multirow[t]{2}{*}{$\overline{T Y P}$} & Typ1 & 2,872 & 25.6 & 2,665 & 24.2 & 3,192 & 26.6 & 669 & 20.8 & 369 & 23.2 \\
\hline & Тур 2 & 8,347 & 74.4 & 8,338 & 75.8 & 8,792 & 73.4 & 2,554 & 79.2 & 1,223 & 76.8 \\
\hline \multirow[t]{3}{*}{$A V A$} & Aval & 92 & 36.58 & 4,073 & 37.0 & 4,150 & 34.5 & $1,2+J$ & 38.6 & 694 & 43.6 \\
\hline & Ava2 & 698 & 59.7 & 6,532 & 59.4 & 7,377 & 61.6 & 1,898 & 58.9 & 867 & 54.5 \\
\hline & Ava3 & 429 & 3.8 & 398 & 3.6 & 469 & 3.9 & 80 & 2.5 & 31 & 1.9 \\
\hline \multirow[t]{2}{*}{$J O B$} & Job1 & 4,347 & 38.7 & 4,393 & 39.9 & 4,631 & 38.6 & 1,304 & 40.5 & 692 & 43.5 \\
\hline & Job2 & 6,872 & 61.3 & 6,610 & 60.1 & 7,353 & 61.4 & 1,919 & 59.5 & 900 & 56.5 \\
\hline \multirow[t]{3}{*}{ TIM } & Tim1 & 2,541 & 22.6 & 2,473 & 22.5 & 2,691 & 22.5 & 775 & 24.0 & 467 & 29.3 \\
\hline & $\operatorname{Tim} 2$ & 4,686 & 41.8 & 4,657 & 42.3 & 5,140 & 42.9 & 1,334 & 41.4 & 666 & 41.8 \\
\hline & $\operatorname{Tim} 3$ & 3,992 & 35.6 & 3,873 & 35.2 & 4,153 & 34.7 & 1,114 & 34.6 & 459 & 28.8 \\
\hline \multirow[t]{2}{*}{$P L A$} & Pla1 & 35 & 22.6 & 6 & 22.0 & 2,752 & 23.0 & 741 & 23.0 & 388 & 24.4 \\
\hline & Pla2 & 8,684 & 77.4 & 8,587 & 78.0 & 9,232 & 77.0 & 2,482 & 77.0 & 1,204 & 75.6 \\
\hline \multirow{3}{*}{\multicolumn{2}{|c|}{$\begin{array}{r}\text { WAG Wag1 } \\
\text { Wag2 } \\
\text { Wag3 }\end{array}$}} & 3 & 3 & & 5 & 3 & 28.3 & 64 & 29.9 & 454 & 28.5 \\
\hline & & 4,358 & 38.8 & 4,221 & 38.4 & 3,843 & 32.1 & 1,182 & 36.7 & 543 & 34.1 \\
\hline & & 88 & 31.1 & 3, & 31.1 & 8 & 39.6 & 1,077 & 33.4 & 595 & 37. \\
\hline \multirow[t]{2}{*}{$R E G$} & Reg1 & 8,600 & 76.7 & 8,506 & 77.3 & 9,338 & 77.9 & 2,585 & 80.2 & 1,361 & 85.5 \\
\hline & Reg2 & 2,619 & 23.3 & & 22.7 & 6 & 22.1 & 638 & 19.8 & 231 & 14. \\
\hline \multirow{2}{*}{\multicolumn{2}{|c|}{$\begin{array}{r}\text { NUM Num1 } \\
\text { Num2 }\end{array}$}} & 5,583 & 49.8 & 5,591 & 50.8 & 5,301 & 44.2 & 1,745 & 54.1 & 827 & 51.9 \\
\hline & & 5,636 & 50.2 & 5, & 49.2 & 6,683 & 55.8 & 1,478 & 45.9 & 765 & 48.1 \\
\hline \multirow[t]{3}{*}{$D U R$} & Dur1 & 3,552 & 31.7 & 76 & 32.5 & 3,777 & 31.5 & 775 & 24.0 & 0 & \\
\hline & Dur2 & 2,282 & 20.3 & 2,151 & 19.5 & 2,244 & 18.7 & 676 & 21.0 & 349 & 21.9 \\
\hline & Dur3 & 5,385 & 48.0 & 5,276 & 48.0 & 5,963 & 49.8 & 1,772 & 55.0 & 1,243 & 78.1 \\
\hline \multirow[t]{2}{*}{$B E N$} & Ben 1 & 559 & 5.0 & 665 & 6.0 & 565 & 4.7 & 134 & 4.2 & 25 & 1.6 \\
\hline & Ben2 & 10,660 & 95.0 & 10,338 & 49.2 & 11,419 & 95.3 & 3,089 & 95.8 & 1,567 & 98.4 \\
\hline \multicolumn{2}{|c|}{ Total } & 11,219 & 100.0 & 11,003 & 100.0 & 11,984 & 100.0 & 3,223 & 100.0 & 1,592 & 100.0 \\
\hline
\end{tabular}

\section{Is there a factor which may be interpreted in terms of choosiness? Evidence from multiple correspondence analysis}

\subsection{Multiple correspondence analysis: some essential notes}

MCA is a descriptive statistical technique that simultaneously represents a set of qualitative variables in a space of reduced dimensionality. Broadly speaking, it may be viewed as the analogueof principal components analysis when the measurements are categorical instead of continuous. To make the paper self-contained, we summarize here some basic features of MCA (for details, see Lebart, Morineau \& Warwick, 1984, and Greenacre \& Blasius, 1994).

MCA consists of the search for underlying factors in the data, by computing the eigenvalues and eigenvectors of a transformation of the original $n \times p$ data matrix, where $n$ is the number of units and $p$ is the total number of mutually exclusive categories of the set of qualitative variables under consideration. The result is the representation of $p$ categories in a factorial space of smaller 
dimension, the axes of the factorial space - or factors, as they are also called - being linear combinations of the categories themselves. The factors are ordered from largest to smallest, according to the portion of total variance accounted for by each of them.

The results of an MCA are summarized by the following quantities: (i) factorial coordinates,

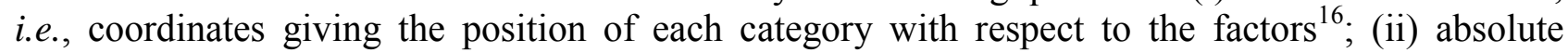
contributions, which indicate the (\%) proportion of variance explained by each category in relation

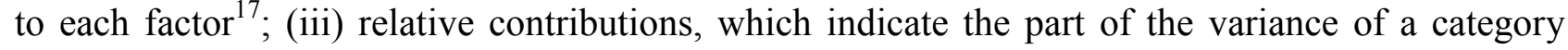
explained by a factor. They are also typically presented on graphs which represent configurations of points (i.e., categories) in projection planes formed by the first factors 18 .

To interpret the results of an MCA, we must take into account both points with larger absolute contributions and points with better relative contributions, which are likely to be far distant from the origin of the axes. The former are the categories which better explain the factor under consideration; the latter are the categories better explained by that factor. Thus, it is easily possible for a category to contribute poorly to the building of a factor, but, in spite of this, to be highly correlated with that same factor. The points close to the origin of the axes neither characterize nor are characterized by the factors themselves: they have undifferentiated distribution among the units, and consequently little informative value.

Moreover, results may often be better interpreted by adding supplementary variables to the so-called active variables - i.e., the variables directly used in MCA for computing the factors. The points (i.e., categories) corresponding to these supplementary variables are also positioned on the factorial plane, and may shed some light in interpreting the factors.

\subsection{The first factor interpreted in terms of choosiness}

The issue to be addressed is whether the results of MCA allow us to detect a factor which may be sensibly interpreted in terms of choosiness.

First, we need to ascertain if such a factor can be recognized, in the sense that the categories of all the active variables take on factorial coordinates consistent with ranking along a flexibility/choosiness axis. Such a factor should possibly be among the first ones; in other words, it should explain an appreciable portion of total variance.

Table 4 and Figure 1 present the results for the 1997.IV sample. The first factor accounts for $17.5 \%$ of total variance and can definitively be interpreted as an axis going from flexibility to choosiness. Quite similar results were obtained for the 1998.I and 1998.IV samples and for the two panels of continuous job-seekers ${ }^{19}$. They provide prima facie evidence of the robustness of our findings.

Looking at the MCA results more closely, two points are worth noting. First, the variables are quite dispersed, so that a considerable number of factors is needed to account for their variance: the first four factors account for only $53.9 \%$ of the variance (the fourth factor contributes $10.6 \%$ ), and the tenth factor still explains $5 \%$. Hence, it is reasonable to acknowledge that, in addition to the dimension of choosiness represented by the first factor, other appreciable latent dimensions - and conceivably also sizeable noise - underline the variability of survey responses to the questions about search/availability/preferences for work.

\footnotetext{
${ }^{16}$ Note that factorial coordinates are invariant with respect to axis translations.

17 The absolute contributions of the categories of a given variable may be summed up, thus giving the overall contribution of the variable to the variance of the factor.

${ }^{18}$ In this representation, the relative contribution of a category depends on the angle between the vector which represents that category and the relevant axis. The smaller the angle, the more the category is correlated with the factor.

${ }^{19}$ Detailed results are available from the authors on request. In summary, the portion of variance explained by the first factor stays within the range 17.3-17.5\%; the factorial coordinates of the active variable categories exhibit consistently coherent ranking along the flexibility/choosiness axis; their numerical values are reasonably close across the various samples.
} 
Second, the contribution of the variables to the first factor, as assessed mainly by the sum of absolute contributions of the relevant categories, is quite diversified. TIM, JOB and AVA dominate; $R E G$ plays a definitely lower, but still appreciable role; TYP, PLA and WAG contribute very modestly. Thus, it appears that the choosiness of job-seekers - as captured by the first factor of multiple correspondence analysis - is characterized mainly in terms of selectivity with respect to working time regime, type of job, and immediate availability for work. However, for the purpose of constructing summary indicators of choosiness, we will use all seven active variables, suitably weighted, because TYP, PLA and WAG also exhibit the expected ranking along the first axis.

A graphical representation is given in Figure 2, in which the categories of some supplementary variables - gender, education, geographic area, labour force state - are also projected on to the space generated by the first two factorial axes - the flexibility/choosiness axis

Table 4: Multiple correspondence analysis on job seekers, 1997.IV: selected results for first factor

\begin{tabular}{|c|c|c|c|c|c|}
\hline \multirow{2}{*}{\multicolumn{2}{|c|}{$\begin{array}{l}\text { Variables and } \\
\text { categories }\end{array}$}} & \multicolumn{4}{|c|}{ Results for the first factor $(N=11,219)$} \\
\hline & & Coordinates & Translated & Absolute & Weighted distances \\
\hline \multirow[t]{2}{*}{$T Y P$} & Typ1 & -.25196 & .00000 & 9 & .00000 \\
\hline & Тур2 & .08669 & .33865 & 3 & 4.22364 \\
\hline \multirow[t]{3}{*}{$A V A$} & Ava1 & -.70582 & .00000 & 104 & .00000 \\
\hline & Ava2 & .37115 & 1.07697 & 47 & 182.98259 \\
\hline & Ava3 & .93762 & 1.64344 & 19 & 279.22867 \\
\hline \multirow[t]{2}{*}{$J O B$} & Job1 & -.92584 & .00000 & 190 & .00000 \\
\hline & Job2 & .58566 & 1.51150 & 120 & 467.96493 \\
\hline \multirow[t]{3}{*}{ TIM } & Tim1 & -1.40430 & .00000 & 255 & .00000 \\
\hline & $\operatorname{Tim} 2$ & .22290 & 1.62720 & 12 & 566.41042 \\
\hline & $\operatorname{Tim} 3$ & .63222 & 2.03652 & 81 & 708.89021 \\
\hline \multirow[t]{2}{*}{$P L A$} & Pla1 & -.45874 & .00000 & 27 & .00000 \\
\hline & Pla2 & .13391 & .59265 & 8 & 20.78779 \\
\hline \multirow[t]{3}{*}{$W A G$} & Wag1 & -.30112 & .00000 & 16 & .00000 \\
\hline & Wag2 & -.04694 & .25418 & 0 & 9.60292 \\
\hline & Wag3 & .34984 & .65096 & 22 & 24.59327 \\
\hline \multirow[t]{2}{*}{$R E G$} & Reg1 & -.21550 & .00000 & 20 & .00000 \\
\hline & Reg2 & .70765 & .92315 & 67 & 80.38421 \\
\hline
\end{tabular}

Proportion of variance explained by the first factor $=17.51 \%$ 
being the horizontal one. Clearly, the categories of the supplementary variables are positioned, with respect to the first axis, consistently in accordance with expectations. Among job-seekers, women are more choosy than men; more educated people are more choosy than less educated ones; people from the relatively well-developed North of Italy are definitely more choosy than people from the South, comparatively less developed and with high unemployment; employed job seekers are positively more choosy than unemployed job losers and first job-seekers. Thus, the overall evidence from the positions of the supplementary variable categories supports the interpretation of the first

Figure 1: Multiple correspondence analysis on job-seekers, 1997.IV: projection of categories of active variables on first factorial axis

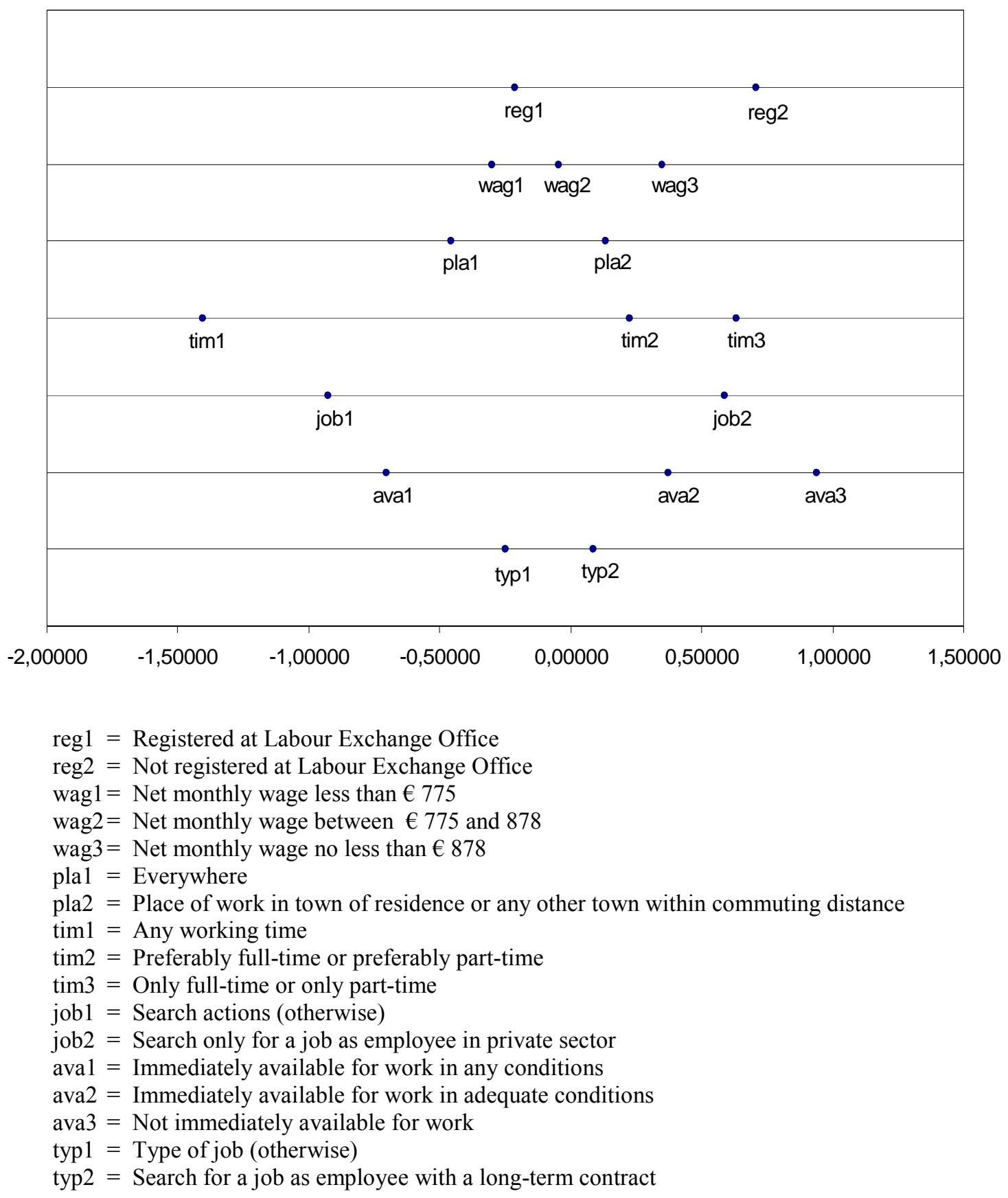


Figure 2: Multiple correspondence analysis on job-seekers, 1997.IV: projection of categories of active and supplementary variables on first two factorial axes

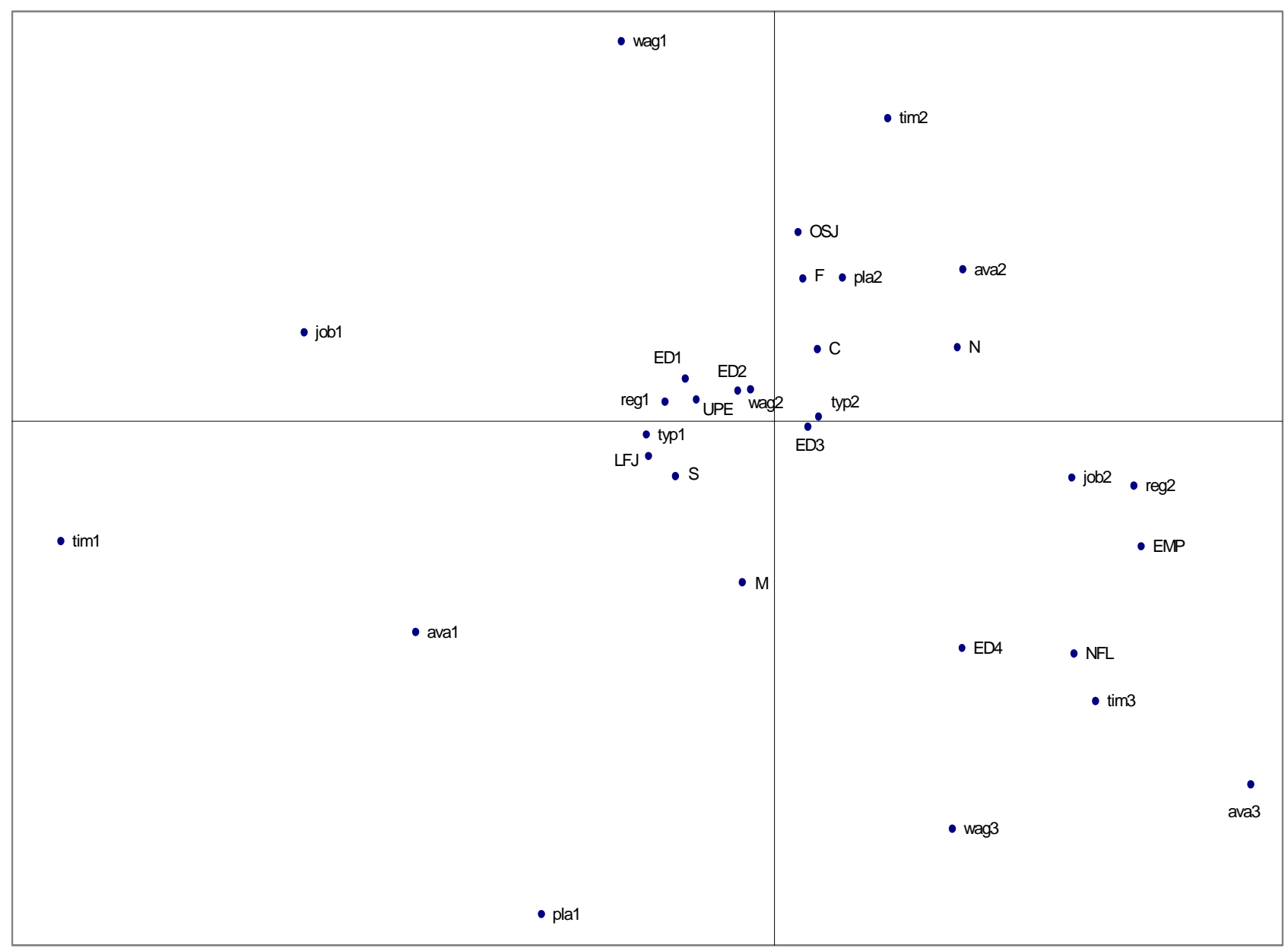

$\mathrm{ED} 1=$ Elementary education $(5$ years $)$ or less

$\mathrm{ED} 2=$ Compulsory $(8$ years $)$

ED3 $=$ Upper secondary (11-13 years)

ED4 $=$ University degree

$\mathrm{N}=$ North

$\mathrm{C}=$ Centre

$\mathrm{S}=$ South

$\mathrm{M}=$ Males

$\mathrm{F}=$ Females

$\mathrm{EMP}=$ Employed

$\mathrm{UPE}=$ Unemployed, previously employed

LFJ $=$ Looking for a first job

OSJ $=$ Others seeking a job

$\mathrm{OLF}=$ Out of labour force

For categories of active variables, see Figure 1. 
axis as a 'choosiness' factor ${ }^{2}$.

\section{Summary indicators of choosiness}

We move now to the construction of the indicator of choosiness, first at individual level and then, by aggregation, for the entire population of job-seekers or for convenient sub-sets of it.

The first step consists of obtaining a concise indicator for single job-seekers, which summarizes the choosiness of their supply. For this purpose, we need to choose appropriately a metric for the categories of each variable and a weighting system for aggregating the variables.

Reasonable solutions are given:

(a) to the metric issue, by the translated factorial coordinates of the categories of a given variable $j$, the translation being such that the category associated with minimum choosiness takes on a value of zero;

(b) to the weighting issue, by adding up the absolute contributions of the various categories of each variable. The sum of the absolute contributions for variable $j$ is used as the factorial weight for all the categories of that variable.

These choices are intuitively convincing. In addition, defining the metric and the weighting system through MCA also has the advantage of minimizing discretion in the aggregation procedure. Furthermore, by using fixed weights for the various categories of a given variable, the ratios between the distances among categories, induced by the metric along the factorial axis, are preserved 21 .

The resulting indicator is then standardized by dividing it by its maximum admissible value. In conclusion, the indicator of choosiness for individual $i$ is defined as follows:

$$
C_{i}=\sum_{j=1}^{7} l_{i, j} w_{j} / \max \left(\sum_{j=1}^{7} l_{j} w_{j}\right)
$$

where $l_{i, j}$ are the translated factorial coordinates associated with the categories of variable $j(j=1$, $\ldots, 7$ ) for individual $i$, and $w_{j}$ are the weights as defined in (b). Clearly, the range for $C_{i}$ is $[0,1]$.

When dealing with sample data, as in our case, we must attach a sample weight to each unit, in order to estimate the population (or sub-population distribution of the indicator or an aggregate (mean) indicator of that population. The corresponding weighted indicator for a generic set of $N$ job-seekers is given by:

$$
C_{i}^{W}=C_{i} p_{i} / \sum_{i}^{N} p_{i}
$$

where $p_{i}$ are the sample weights for individual $i$.

The weighted mean indicator for a generic set of $N$ job-seekers is simply given by:

$$
C=\sum_{i=1}^{N} C_{i}^{W}
$$

The distribution of $C_{i}^{W}$ among job-seekers in 1997.IV is shown in Figure 3, for the entire pool of job-seekers and separately by gender, geographic area, and detailed labour force state.

\footnotetext{
${ }^{20}$ Note, on the contrary, that the interpretation of the second axis is problematic. Indeed, the categories of WAG (i.e., minimum net monthly wage) turn out to be well dispersed and consistently ordered from the first to the third, perhaps suggesting a dimension of 'expected monetary reward'. But the ranking of the categories of other active variables - and also of the supplementary variables - is difficult to explain.

${ }^{21}$ Alternatively, we could have used factorial weights, i.e., the (\%o) absolute contributions of each category. This choice would have produced qualitatively similar but less polarized results, with a less straightforward interpretation.
} 
Figure 3: Distribution by deciles (\%) of the indicator of choosiness among job seekers, by gender, geographic area and detailed labour force state (1997.IV, weighted).

Total

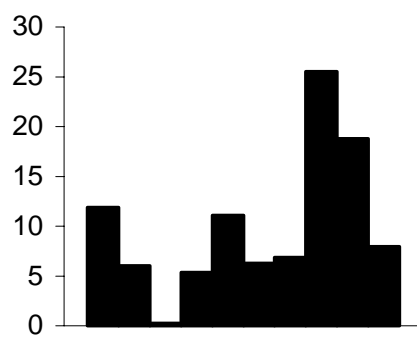

North

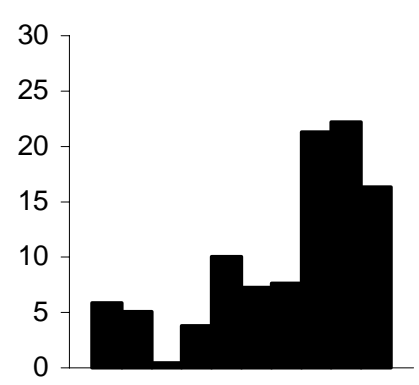

Unemployed previously employed

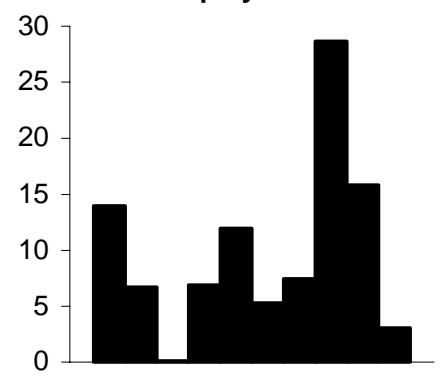

Employed

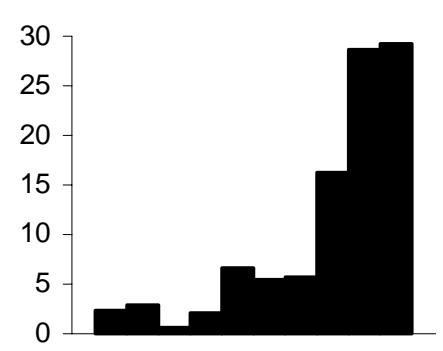

Males

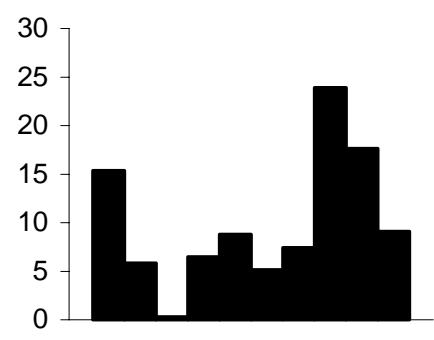

Centre

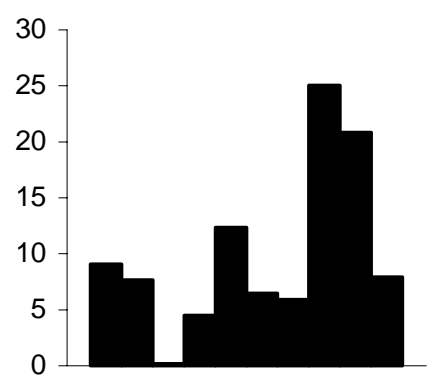

Looking for the first job

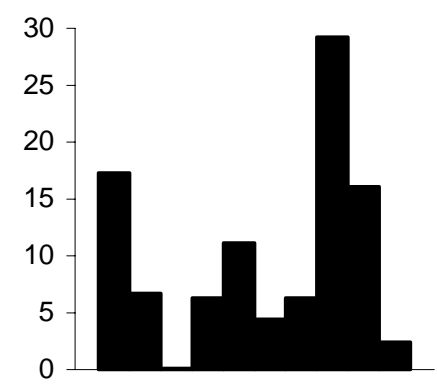

Unemployed total

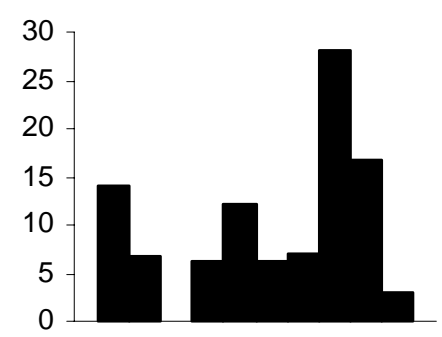

Females

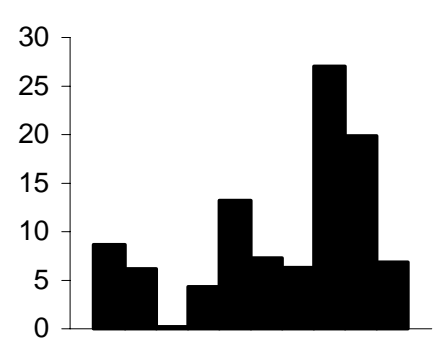

South

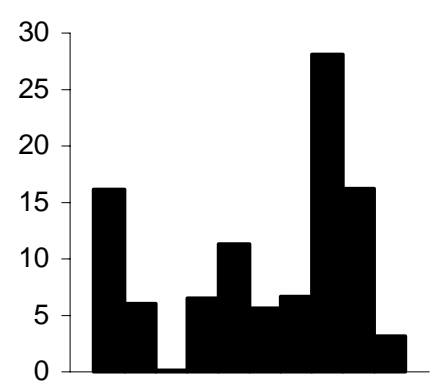

Others seeking a job

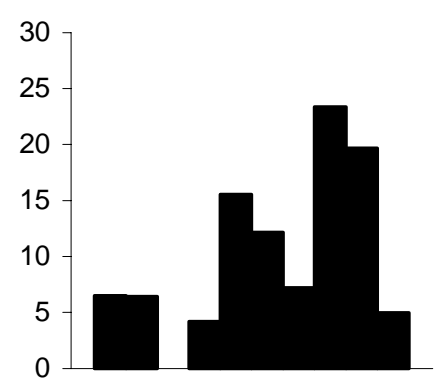

Out of the labour force

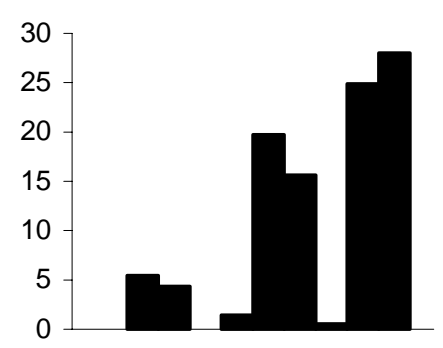


Although with non-negligible variations between groups, the distributions are quite well polarized: most of them are bimodal, U-shaped. About $50 \%$ of job-seekers are quite choosy, with $C_{i}^{W} \geq .7$, and with a sizeable spike mostly at $.7 \leq C_{i}^{W}<.8$. Instead, the first part of the distribution tends to be more even, with a moderate spike at $.0 \leq C_{i}^{W}<.1$, identifying people who are not at all selective with respect to potential job offers. In short, with respect to the weighted individual indicator of choosiness, the dominant pattern points to a clear distinction between two types of jobseekers: highly and poorly choosy respectively. Interestingly enough, the spike on the latter type is more pronounced for men, in the South, and for unemployed job losers or looking for their first job.

\section{Stability and predictive power of the indicator}

\subsection{Stability}

Before looking at the empirical results for Italy, it is worth examining the measurement properties of the individual indicator of choosiness, and of the observed survey variables used to construct it. Ideally, one would like to assess the reliability of these measures in an experimental setting, i.e., under invariance conditions as regards both the labour force state of the individual and other personal and environmental variables. Unfortunately, such data are not at our disposal.

A proxy for reliability analysis is provided by stability analysis, i.e., assessing the agreement of the measures over the same individuals, facing approximately the same labour force condition, in two subsequent survey occasions. Our 1997.IV-1998.I and 1997.IV-1998.IV panels fit this purpose. As pointed out in Section 2, they are confined to persons who, during the three-month and twelvemonth periods separating the two survey occasions, were continuously looking for a job. These indeed, only these - sets of persons answered the questions on search/availability/preferences on both occasions.

One point must be stressed. The mere fact that time passes destroys the coeteris paribus condition. It is reasonable to assume that people continuously looking for a job will become less choosy with time precisely because their spell of job search lengthens, the main explanation being that most job-seekers are liquidity-constrained 22 . This is the main reason why our stability analysis is an approximation to proper reliability analysis. Conversely, under the assumption of choosiness declining with job search duration, our stability indicators should be viewed as lower limits to the true, unobservable reliability indicators. In other words, the measurement properties of the survey variables on search/availability/preferences for work, as well as of the individual indicators of choosiness, will be at least no worse than the corresponding stability properties assessed by empirical analysis over the panels of continuous job-seekers.

We also attempt to reduce the distance from the coeteris paribus condition by controlling for variations in the labour force state 23 . In fact, a change in labour force state (for instance, from "Unemployed, previously employed" to "Employed" looking for another job) is likely to induce some changes in the answers to our set of questions. To contain, at least partly, the perturbing effects of changes in conditions at the individual level, stability analysis was carried out on convenient sub-sets of job-seekers characterised by different degrees of labour force state invariance. For this purpose, we considered various sets of job-seekers (their size is given in brackets for the quarterly panel):

(I) the sub-set of persons continuously employed (363);

\footnotetext{
${ }^{22}$ The argument parallels the explanation for a declining reservation wage: see, e.g., Mortensen (1986), pp. 859-861. As will be seen in the sequel, this idea is consistent with our empirical findings.

${ }^{23}$ Within the ILFS, in principle it is possible to control for other factors of individual change (such as marital status, household size, labour force state of other household members, etc.), which are likely to affect the responses to survey questions on the search for work. However, this exercise would be quite cumbersome, and perhaps not rewarding because of poor short-term individual changes in those factors and sample size constraints.
} 
(II) the sub-set of persons continuously unemployed and previously employed (891);

(III) the sub-set of persons continuously looking for their first job $(1,153)$;

(IV) the sub-set of persons continuously classified as "Others looking for a job" (353);

(V) the sub-set of unemployed persons continuously belonging to the same sub-group (II+III+IV: 2,397);

(VI) the sub-set of persons continuously unemployed, in a broad sense $(2,654)$;

(VII) the sub-set of persons continuously out of the labour force (22);

(VIII) the sub-set of persons looking for a job who continuously belonged to the same sub-group (I+V+VII: 2,782);

(IX) the overall panel of persons continuously looking for a job, irrespective of their labour force state on the two survey occasions $(3,223)$.

Strict labour force state invariance holds for groups I-IV, VII and VIII. Suitable comparisons can also be made between group $\mathrm{V}$, resulting from aggregation of the invariant sub-groups of continuously unemployed persons, and group VI, which comprises the overall set of persons continuously unemployed and thus is quite similar except for a lower degree of invariance; and, analogously, between groups VIII and IX.

For both quarterly and yearly panels, for each of these sub-samples we assess the stability of results with reference to a two-way square table representing the cross-tabulation of the variable of interest on the two survey occasions. More precisely, we evaluate:

(a) The agreement of responses for each of the seven survey variables, measured by Cohen's $\kappa$ statistic. Simply stated, Cohen's $\kappa$ is an index of the proportion of agreement above chance, with reference to a nominal classification. It is 0 when agreement equals that expected by chance, and is 1 when there is perfect agreement (see, e.g., Agresti, 1990, pp. 366-367).

(b) The agreement of individual indicators of choosiness $C_{i}$, measured by three statistics: Cohen's $\kappa$, Weighted $\kappa^{25}$, and the correlation coefficient. The latter coefficient exploits the continuous scale for $C_{i}$, the two former indices are computed from the $10 \times 10$ cross-tabulation of $C_{i}$ by deciles.

(c) The change in choosiness moving from the first survey occasion to the second, for the sub-set of cases of non-agreement as revealed by the $10 \times 10$ cross-distribution of $C_{i}$ by deciles. Let us consider only the frequencies outside the main diagonal, i.e., those associated with different measurements on the two survey occasions. Let us call the sum of relative frequencies above the main diagonal $a$, and the sum of relative frequencies below it $b$. A simple, convenient index of change in choosiness is given by:

$H=\frac{a-b}{a+b}$.

$H$ varies from -1 (all relevant frequencies below the main diagonal) to +1 (all relevant frequencies above it), 0 being the threshold discriminating downward from upward change $\frac{26}{\text {. It }}$ is worth emphasizing that $H$ is not an index of stability. Rather, it measures the direction of change, normalised in $[-1,+1]$ and, for proper interpretation, it must be assessed jointly with

\footnotetext{
${ }^{24}$ We use $C_{i}$ instead of $C_{i}^{W}$, because we don't have weights for the panels.

${ }^{25}$ Weighted $\kappa$ is appropriate when categories are numerous and ordered, because in these circumstances the seriousness of any disagreement depends on the difference between ratings. (Also for nominal politomous classifications, some disagreements may be considered more substantial than others). Weighted $\kappa$ allows each cell $i, j$ to be suitably weighted according to the seriousness of disagreement between the $i$-th and $j$-th categories, for $i \neq j$. We used the weights $w_{i j}=1-\left|S_{i}-S_{j}\right| /\left(S_{R}-S_{1}\right)$, where $S_{i}$ is the score for column $i$ and $R$ is the number of categories. The asymptotic variance of Cohen's $\kappa$ and that of Weighted $\kappa$ were computed according to Fleiss et al. (1969).

${ }^{26} \mathrm{H}$ is indeterminate in the case of perfect agreement.
} 
the corresponding indices of stability. Under the assumption of choosiness declining with search tenure, we anticipate that $H$ will be negative and, coeteris paribus, will diminish as the ongoing spell of job search lengthens.

Results for the quarterly panel are shown in Tables 5 and 6 and are quite satisfactory. The main evidence may be summarized in a few statements. First, consistently with expectations, the change in choosiness is modest, but systematically downward $(H$ around -.1$)$. Also, the decrease in choosiness for continuously employed job-seekers is almost negligible $(H=-.02)$ - much lower in absolute terms than the decrease for the unemployed $(H=-.104$ for those continuously in the same condition), which is also as expected. Second, stability is quite high, as appears from inspection of both Cohen's $\kappa$ for single variables entering the indicator of choosiness (systematically above .5 , and above .7 in $40 \%$ of cases) and the three coefficients of agreement of the indicator of choosiness itself. Lastly, the closer the degree of labour force state invariance, the higher the stability. Comparison of the various coefficients for groups V vs. VI and groups VIII vs. IX does not reveal any violation of this pattern.

Table 5: Stability of responses to single variables entering indicator of choosiness, for people continuously looking for a job, from panel 1997.IV-1998.I (N=3,223): Cohen's $\kappa$ for various subgroups of job-seekers

\begin{tabular}{|c|c|c|c|c|c|c|c|c|c|}
\hline \multirow[t]{2}{*}{ Variables* } & \multicolumn{9}{|c|}{ Cohen's $\kappa$ (asymptotic standard errors between brackets) } \\
\hline & $\begin{array}{c}\text { I. } \\
\text { Continuous } \\
\text { ly em- } \\
\text { ployed }\end{array}$ & $\begin{array}{c}\text { II. } \\
\text { Cont.ly } \\
\text { unempl. } \\
\text { Previously } \\
\text { employed }\end{array}$ & $\begin{array}{c}\text { III. } \\
\text { Cont.ly } \\
\text { looking for } \\
\text { a first job }\end{array}$ & $\begin{array}{c}\text { IV. } \\
\text { Cont.ly } \\
\text { others } \\
\text { looking for } \\
\text { a job }\end{array}$ & $\begin{array}{c}\text { V. } \\
\text { Unempl. } \\
\text { cont.ly in } \\
\text { the same c. } \\
\text { (II+III+IV) }\end{array}$ & $\begin{array}{c}\text { VI. } \\
\text { Cont.ly } \\
\text { unemploye } \\
\text { d: total }\end{array}$ & $\begin{array}{c}\text { VII. } \\
\text { Cont.ly out } \\
\text { of labour } \\
\text { force }\end{array}$ & $\begin{array}{l}\text { VIII. } \\
\text { Cont.ly in } \\
\text { the same } \\
\text { condition } \\
\text { (I+V+VII) }\end{array}$ & $\begin{array}{c}\text { IX. } \\
\text { Cont.ly } \\
\text { Actively } \\
\text { looking for } \\
\text { a job }\end{array}$ \\
\hline$T Y P$ & $\begin{array}{l}.580 \\
(.061)\end{array}$ & $\begin{array}{l}.513 \\
(.037)\end{array}$ & $\begin{array}{l}.544 \\
(.029)\end{array}$ & $\begin{array}{l}.687 \\
(.045)\end{array}$ & $\begin{array}{l}.559 \\
(.021)\end{array}$ & $\begin{array}{l}.546 \\
(.020)\end{array}$ & $\begin{array}{l}.421 \\
(.164)\end{array}$ & $\begin{array}{l}.561 \\
(.019)\end{array}$ & $\begin{array}{l}.549 \\
(.018)\end{array}$ \\
\hline$A V A$ & $\begin{array}{c}.758 \\
(.040)\end{array}$ & $\begin{array}{l}.730 \\
(.023)\end{array}$ & $\begin{array}{l}.731 \\
(.020)\end{array}$ & $\begin{array}{c}.662 \\
(.047)\end{array}$ & $\begin{array}{c}.731 \\
(.014)\end{array}$ & $\begin{array}{l}.703 \\
(.014)\end{array}$ & $* *$ & $\begin{array}{l}.749 \\
.013)\end{array}$ & $\begin{array}{l}.694 \\
(.013)\end{array}$ \\
\hline$J O B$ & $\begin{array}{l}.667 \\
(.051)\end{array}$ & $\begin{array}{l}.649 \\
(.026)\end{array}$ & $\begin{array}{l}.720 \\
(.020)\end{array}$ & $\begin{array}{l}.715 \\
(.038)\end{array}$ & $\begin{array}{l}.695 \\
(.015)\end{array}$ & $\begin{array}{l}.677 \\
(.014)\end{array}$ & $\begin{array}{l}.817 \\
(.124)\end{array}$ & $\begin{array}{l}.702 \\
(.014)\end{array}$ & $\begin{array}{l}.677 \\
(.013)\end{array}$ \\
\hline$T I M$ & $\begin{array}{l}.716 \\
(.034)\end{array}$ & $\begin{array}{l}.663 \\
(.021)\end{array}$ & $\begin{array}{l}.733 \\
(.017)\end{array}$ & $\begin{array}{l}.646 \\
(.036)\end{array}$ & $\begin{array}{l}.696 \\
(.012)\end{array}$ & $\begin{array}{l}.677 \\
(.012)\end{array}$ & $\begin{array}{c}.687 \\
(.135)\end{array}$ & $\begin{array}{l}.702 \\
(.012)\end{array}$ & $\begin{array}{l}.677 \\
(.011)\end{array}$ \\
\hline PLA & $\begin{array}{l}.721 \\
(.047)\end{array}$ & $\begin{array}{l}.690 \\
(.031)\end{array}$ & $\begin{array}{l}.628 \\
(.025)\end{array}$ & $\begin{array}{l}.648 \\
(.058)\end{array}$ & $\begin{array}{l}.658 \\
(.018)\end{array}$ & $\begin{array}{l}.639 \\
(.018)\end{array}$ & $\begin{array}{l}.593 \\
(.200)\end{array}$ & $\begin{array}{l}.665 \\
(.017)\end{array}$ & $\begin{array}{l}.647 \\
(.016)\end{array}$ \\
\hline$W A G$ & $\begin{array}{l}.723 \\
(.032)\end{array}$ & $\begin{array}{l}.673 \\
(.021)\end{array}$ & $\begin{array}{l}.650 \\
(.019)\end{array}$ & $\begin{array}{c}.661 \\
(.034)\end{array}$ & $\begin{array}{l}.662 \\
(.013)\end{array}$ & $\begin{array}{l}.651 \\
(.012)\end{array}$ & $\begin{array}{c}.777 \\
(.119)\end{array}$ & $\begin{array}{l}.675 \\
(.012)\end{array}$ & $\begin{array}{c}.660 \\
(.011)\end{array}$ \\
\hline$R E G$ & $\begin{array}{c}.854 \\
(.028)\end{array}$ & $\begin{array}{l}.766 \\
(.032)\end{array}$ & $\begin{array}{l}.768 \\
(.029)\end{array}$ & $\begin{array}{l}.841 \\
(.033)\end{array}$ & $\begin{array}{l}.788 \\
(.018)\end{array}$ & $\begin{array}{l}.774 \\
(.017)\end{array}$ & $\begin{array}{l}1.000 \\
(.000)\end{array}$ & $\begin{array}{l}.833 \\
(.013)\end{array}$ & $\begin{array}{l}.806 \\
(.013)\end{array}$ \\
\hline Sample size & 363 & 891 & 1,153 & 353 & 2,397 & 2,654 & 22 & 2,782 & 3,223 \\
\hline
\end{tabular}

* See Table 2 for variables description.

** All observations in cell $(3,3)$. 
The results for the 1997.IV-1998.IV panel largely mimic previous ones (see Tables 7 and 8). Of course, some differences must be taken into account: a yearly panel of continuous job-seekers is more selected; the stability of responses to single survey variables - and of the indicator of choosiness - one year later is arguably lower. And this is precisely what we find. Apart from this, the decrease in choosiness of unemployed persons over one year is much higher than over a quarter ( $H=-.193$ vs. -.104$)$; stability remains reasonably high; the pattern of stability across sub-groups systematically favours groups which higher labour force invariance.

The overall evidence from $H$ and the stability indices allows us to draw two broad conclusions: (i) the stability measures are lower limits for the reliability of the corresponding indicators; (ii) stability, and thus indirectly reliability, is remarkably high, and our results should be regarded as robust.

Table 6: Stability of indicator of choosiness for people continuously looking for a job from panel 1997.IV-1998.I $(N=3,223)$

\begin{tabular}{|c|c|c|c|c|c|}
\hline \multirow{2}{*}{$\begin{array}{l}\text { Groups of persons } \\
\text { continuously looking for } \\
\text { a job }\end{array}$} & \multicolumn{3}{|c|}{$\begin{array}{c}\text { Coefficients of agreement } \\
{[90 \% \text { confidence intervals between brackets }]}\end{array}$} & \multirow[b]{2}{*}{ Index $H$} & \multirow[t]{2}{*}{$\begin{array}{l}\text { Sample } \\
\text { size }\end{array}$} \\
\hline & Cohen's $\kappa$ & Weighted $\kappa$ & $\begin{array}{l}\text { Correlation } \\
\text { coefficient }\end{array}$ & & \\
\hline $\begin{array}{l}\text { I. Continuously } \\
\text { Employed }\end{array}$ & $\begin{array}{c}.644 \\
{[.596 ; .692]}\end{array}$ & $\begin{array}{c}.723 \\
{[.670 ; .776]}\end{array}$ & $\begin{array}{c}.782 \\
{[.749 ; .815]}\end{array}$ & -.020 & 363 \\
\hline $\begin{array}{l}\text { II. Cont.ly unemployed } \\
\text { previously employed }\end{array}$ & $\begin{array}{c}.557 \\
{[.525 ; .588]}\end{array}$ & $\begin{array}{c}.670 \\
{[.638 ; .703]}\end{array}$ & $\begin{array}{c}.743 \\
{[.718 ; .768]}\end{array}$ & -.076 & 891 \\
\hline $\begin{array}{l}\text { III. Cont.ly looking for a } \\
\text { first job }\end{array}$ & $\begin{array}{c}.609 \\
{[.582 ; .636]}\end{array}$ & $\begin{array}{c}.732 \\
{[.706 ; .757]}\end{array}$ & $\begin{array}{c}.796 \\
{[.778 ; .814]}\end{array}$ & -.110 & 1,153 \\
\hline $\begin{array}{l}\text { IV. Cont.ly others looking } \\
\text { for a job }\end{array}$ & $\begin{array}{c}.562 \\
{[.512 ; .611]}\end{array}$ & $\begin{array}{c}.686 \\
{[.638 ; .733]}\end{array}$ & $\begin{array}{c}.762 \\
{[.725 ; .799]}\end{array}$ & -.154 & 353 \\
\hline $\begin{array}{l}\text { V. Unemployed cont.ly in } \\
\text { the same condition } \\
\text { (II+III+IV) }\end{array}$ & $\begin{array}{c}.585 \\
{[.566 ; .603]}\end{array}$ & $\begin{array}{c}.706 \\
{[.687 ; .724]}\end{array}$ & $\begin{array}{c}.776 \\
{[.763 ; .789]}\end{array}$ & -.104 & 2,397 \\
\hline $\begin{array}{l}\text { VI. Cont.ly unemployed: } \\
\text { total }\end{array}$ & $\begin{array}{c}.560 \\
{[.541 ; .578]}\end{array}$ & $\begin{array}{c}.685 \\
{[.667 ; .703]}\end{array}$ & $\begin{array}{c}.756 \\
{[.742 ; .770]}\end{array}$ & -.107 & 2,654 \\
\hline $\begin{array}{l}\text { VII. Cont.ly out of labour } \\
\text { force }\end{array}$ & $\begin{array}{c}.651 \\
{[.458 ; .843]}\end{array}$ & $\begin{array}{c}.708 \\
{[.527 ; .889]}\end{array}$ & $\begin{array}{c}.798 \\
{[.671 ; .925]}\end{array}$ & -.333 & 22 \\
\hline $\begin{array}{l}\text { VIII. Cont.ly in the same } \\
\text { condition (I+V+VII) }\end{array}$ & $\begin{array}{c}.600 \\
{[.583 ; .617]}\end{array}$ & $\begin{array}{c}.720 \\
{[.703 ; .737]}\end{array}$ & $\begin{array}{c}.789 \\
{[.777 ; .801]}\end{array}$ & -.096 & 2,782 \\
\hline $\begin{array}{l}\text { IX. Cont.ly actively } \\
\text { looking for a job }\end{array}$ & $\begin{array}{c}.559 \\
{[.543 ; .576]}\end{array}$ & $\begin{array}{c}.690 \\
{[.674 ; .706]}\end{array}$ & $\begin{array}{c}.764 \\
{[.752 ; .776]}\end{array}$ & -.093 & 3,223 \\
\hline
\end{tabular}


Table 7: Stability of responses to single variables entering indicator of choosiness, for people continuously looking for a job from panel 1997.IV-1998.IV (N=1,592): Cohen's $\kappa$ for various subgroups of job-seekers

\begin{tabular}{|c|c|c|c|c|c|c|c|c|c|}
\hline \multirow[t]{2}{*}{ Variables* } & \multicolumn{9}{|c|}{ Cohen's $\kappa$ (asymptotic standard errors between brackets) } \\
\hline & $\begin{array}{c}\text { I. } \\
\text { Continuous } \\
\text { ly em- } \\
\text { ployed }\end{array}$ & $\begin{array}{c}\text { II. } \\
\text { Cont.ly } \\
\text { unempl. } \\
\text { Previously } \\
\text { employed }\end{array}$ & $\begin{array}{c}\text { III. } \\
\text { Cont.ly } \\
\text { looking for } \\
\text { a first job }\end{array}$ & $\begin{array}{c}\text { IV. } \\
\text { Cont.ly } \\
\text { others } \\
\text { looking for } \\
\text { a job }\end{array}$ & $\begin{array}{c}\text { V. } \\
\text { Unempl. } \\
\text { cont.ly in } \\
\text { the same c. } \\
\text { (II+III+IV) }\end{array}$ & $\begin{array}{c}\text { VI. } \\
\text { Cont.ly } \\
\text { unemploye } \\
\text { d: total }\end{array}$ & $\begin{array}{c}\text { VII. } \\
\text { Cont.ly out } \\
\text { of labour } \\
\text { force** }\end{array}$ & $\begin{array}{c}\text { VIII. } \\
\text { Cont.ly in } \\
\text { the same } \\
\text { condition } \\
\text { (I+V+VII) }\end{array}$ & $\begin{array}{c}\text { IX. } \\
\text { Cont.ly } \\
\text { Actively } \\
\text { looking for } \\
\text { a job }\end{array}$ \\
\hline$T Y P$ & $\begin{array}{c}.596 \\
(.100)\end{array}$ & $\begin{array}{l}.497 \\
(.056)\end{array}$ & $\begin{array}{l}.477 \\
(.041)\end{array}$ & $\begin{array}{c}.496 \\
(.074)\end{array}$ & $\begin{array}{l}.491 \\
(.030)\end{array}$ & $\begin{array}{c}.492 \\
(.028)\end{array}$ & - & $\begin{array}{l}.498 \\
(.029)\end{array}$ & $\begin{array}{l}.482 \\
(.026)\end{array}$ \\
\hline$A V A$ & $\begin{array}{l}.641 \\
(.086)\end{array}$ & $\begin{array}{l}.656 \\
(.039)\end{array}$ & $\begin{array}{l}.664 \\
(.030)\end{array}$ & $\begin{array}{l}.517 \\
(.079)\end{array}$ & $\begin{array}{l}.659 \\
(.022)\end{array}$ & $\begin{array}{l}.641 \\
(.021)\end{array}$ & - & $\begin{array}{l}.665 \\
(.021)\end{array}$ & $\begin{array}{l}.601 \\
(.019)\end{array}$ \\
\hline$J O B$ & $\begin{array}{l}.794 \\
(.081)\end{array}$ & $\begin{array}{l}.644 \\
(.039)\end{array}$ & $\begin{array}{l}.676 \\
(.029)\end{array}$ & $\begin{array}{l}.682 \\
(.060)\end{array}$ & $\begin{array}{l}.667 \\
(.022)\end{array}$ & $\begin{array}{l}.642 \\
(.021)\end{array}$ & - & $\begin{array}{l}.680 \\
(.021)\end{array}$ & $\begin{array}{l}.627 \\
(.020)\end{array}$ \\
\hline$T I M$ & $\begin{array}{l}.699 \\
(.066)\end{array}$ & $\begin{array}{l}.552 \\
(.035)\end{array}$ & $\begin{array}{l}.649 \\
(.025)\end{array}$ & $\begin{array}{l}.638 \\
(.054)\end{array}$ & $\begin{array}{l}.619 \\
(.019)\end{array}$ & $\begin{array}{l}.586 \\
(.018)\end{array}$ & - & $\begin{array}{l}.627 \\
(.018)\end{array}$ & $\begin{array}{l}.567 \\
(.017)\end{array}$ \\
\hline PLA & $\begin{array}{l}.670 \\
(.096)\end{array}$ & $\begin{array}{l}.588 \\
(.053)\end{array}$ & $\begin{array}{l}.556 \\
(.035)\end{array}$ & $\begin{array}{c}.789 \\
(.072)\end{array}$ & $\begin{array}{l}.597 \\
(.027)\end{array}$ & $\begin{array}{l}.590 \\
(.025)\end{array}$ & - & $\begin{array}{l}.603 \\
(.026)\end{array}$ & $\begin{array}{l}.582 \\
(.024)\end{array}$ \\
\hline$W A G$ & $\begin{array}{l}.664 \\
(.067)\end{array}$ & $\begin{array}{l}.587 \\
(.034)\end{array}$ & $\begin{array}{l}.659 \\
(.025)\end{array}$ & $\begin{array}{l}.631 \\
(.052)\end{array}$ & $\begin{array}{l}.634 \\
(.019)\end{array}$ & $\begin{array}{l}.610 \\
(.018)\end{array}$ & - & $\begin{array}{l}.639 \\
(.018)\end{array}$ & $\begin{array}{l}.600 \\
(.017)\end{array}$ \\
\hline$R E G$ & $\begin{array}{c}.892 \\
(.047)\end{array}$ & $\begin{array}{l}.706 \\
(.055)\end{array}$ & $\begin{array}{l}.683 \\
(.048)\end{array}$ & $\begin{array}{l}.826 \\
(.059)\end{array}$ & $\begin{array}{l}.719 \\
(.032)\end{array}$ & $\begin{array}{l}.684 \\
(.031)\end{array}$ & - & $\begin{array}{l}.772 \\
(.025)\end{array}$ & $\begin{array}{l}.716 \\
(.025)\end{array}$ \\
\hline Sample size & 94 & 384 & 638 & 158 & 1,180 & 1,352 & 2 & 1,276 & 1,592 \\
\hline
\end{tabular}

* See Table 2 for variables description.

** Because of the small sample size we don't calculate Cohen's $\kappa$ for this subgroup. 
Table 8: Stability of indicator of choosiness for people continuously looking for a job from panel 1997.IV-1998.IV $(N=1,592)$

\begin{tabular}{|c|c|c|c|c|c|}
\hline \multicolumn{4}{|c|}{$\begin{array}{lc}\text { Groups of persons } & \text { Coefficients of agreement } \\
\text { continuously looking for }[90 \% \text { confidence intervals between brackets }]\end{array}$} & \multirow[b]{2}{*}{ Index $H$} & \multirow[t]{2}{*}{$\begin{array}{l}\text { Sample } \\
\text { size }\end{array}$} \\
\hline a jo & Cohen's $\kappa$ & Weighted $\kappa$ & $\begin{array}{l}\text { Correlation } \\
\text { coefficient }\end{array}$ & & \\
\hline $\begin{array}{l}\text { I. Continuously } \\
\text { Employed }\end{array}$ & $\begin{array}{c}.602 \\
{[.506 ; .697]}\end{array}$ & $\begin{array}{c}.772 \\
{[.696 ; .848]}\end{array}$ & $\begin{array}{c}.889 \\
{[.854 ; .924]}\end{array}$ & .000 & 94 \\
\hline $\begin{array}{l}\text { II. Cont.ly unemployed } \\
\text { previously employed }\end{array}$ & $\begin{array}{c}.500 \\
{[.452 ; .549]}\end{array}$ & $\begin{array}{c}.612 \\
{[.560 ; .664]}\end{array}$ & $\begin{array}{c}.681 \\
{[.636 ; .726]}\end{array}$ & -.175 & 384 \\
\hline $\begin{array}{l}\text { III. Cont.ly looking for a } \\
\text { first job }\end{array}$ & $\begin{array}{c}.537 \\
{[.499 ; .574]}\end{array}$ & $\begin{array}{c}.652 \\
{[.613 ; .692]}\end{array}$ & $\begin{array}{c}.710 \\
{[.678 ; .742]}\end{array}$ & -.253 & 638 \\
\hline $\begin{array}{l}\text { IV. Cont.ly others } \\
\text { looking for a job }\end{array}$ & $\begin{array}{c}.578 \\
{[.503 ; .652]}\end{array}$ & $\begin{array}{c}.669 \\
{[.592 ; .747]}\end{array}$ & $\begin{array}{c}.711 \\
{[.647 ; .775]}\end{array}$ & .018 & 158 \\
\hline $\begin{array}{l}\text { V. Unemployed cont.ly } \\
\text { in the same condition } \\
(\mathrm{II}+\mathrm{III}+\mathrm{IV})\end{array}$ & $\begin{array}{c}.531 \\
{[.503 ; .558]}\end{array}$ & $\begin{array}{c}.644 \\
{[.615 ; .673]}\end{array}$ & $\begin{array}{c}.704 \\
{[.681 ; .727]}\end{array}$ & -.193 & 1,180 \\
\hline $\begin{array}{l}\text { VI. Cont.ly unemployed: } \\
\text { total }\end{array}$ & $\begin{array}{c}.499 \\
{[.473 ; .525]}\end{array}$ & $\begin{array}{c}.612 \\
{[.584 ; .640]}\end{array}$ & $\begin{array}{c}.673 \\
{[.649 ; .697}\end{array}$ & -.147 & 1,352 \\
\hline $\begin{array}{l}\text { VII. Cont.ly out of labour } \\
\text { force* }\end{array}$ & - & - & - & - & 2 \\
\hline $\begin{array}{l}\text { VIII. Cont.ly in the same } \\
\text { condition }(\mathrm{I}+\mathrm{V}+\mathrm{VII})\end{array}$ & $\begin{array}{c}.538 \\
{[.512 ; .565]}\end{array}$ & $\begin{array}{c}.659 \\
{[.631 ; .686]}\end{array}$ & $\begin{array}{c}.721 \\
{[.699 ; .743]}\end{array}$ & -.183 & 1,276 \\
\hline $\begin{array}{l}\text { IX. Cont.ly actively } \\
\text { looking for a job }\end{array}$ & $\begin{array}{c}.477 \\
{[.453 ; .501]}\end{array}$ & $\begin{array}{c}.599 \\
{[.573 ; .625]}\end{array}$ & $\begin{array}{c}.664 \\
{[.641 ; .687]}\end{array}$ & -.106 & 1,592 \\
\hline
\end{tabular}

* No results given because of the small sample size.

\subsection{Predictive power}

A different perspective for assessing the significance of the individual indicator of choosiness consists of looking at its predictive power in gross flows analyses. For this purpose, we restricted our attention to the sub-sets of the 1997.IV-1998.I and 1997.IV-1998.IV overall panels made up of unemployed persons on the initial survey occasion 27 . They consisted of 4,370 and 3,879 persons, respectively.

\footnotetext{
${ }^{27}$ To carry out gross flows analyses meaningfully, we had to condition to the initial state, discarding the additional requirement of continuous job search. We also excluded employed job-seekers, because their 'transition probability' to employment cannot be given any reasonable interpretation. In fact, the flow comprises both stayers in the same job and movers to a different job. Job-seekers out of the labour force were excluded because there were too few of them.
} 
We computed the probabilities of transition to the usual labour force states - employment, unemployment, and out of the labour force - conditional jointly on detailed unemployment condition (job losers, looking for a first job, others seeking a job) and on the level of the individual indicator of choosiness - categorized as low, medium and high. Gross flows estimates were carried out for all the panel samples of initially unemployed, and for sub-groups resulting from breakdown by gender and geographic area.

Table 9 shows that choosiness, as measured by our indicator and as categorized there, does not clearly affect quarterly transition probabilities from unemployment to employment. Indeed, in general and for most sub-groups, transitions appeared to be higher for persons with higher choosiness. Instead, with minor exceptions, the lower the level of choosiness, the lower the probability of leaving the labour force. Less choosy persons show stronger attachment to the labour force, which essentially translates into a greater propensity to continue to search as unemployed.

Table 9: Quarterly transition probabilities (\%) from unemployment by detailed condition, level of indicator of choosiness*, gender and geographic area: panel 1997.IV-1998.I $(N=4,271)$

\begin{tabular}{|c|c|c|c|c|c|c|c|c|c|c|}
\hline \multicolumn{2}{|c|}{ 1997.IV } & \multicolumn{9}{|c|}{ 1998.I } \\
\hline \multirow{2}{*}{$\begin{array}{c}\text { Labour force } \\
\text { state }\end{array}$} & \multirow{2}{*}{$\begin{array}{l}\text { Indicator of } \\
\text { choosiness }\end{array}$} & \multicolumn{3}{|c|}{ Males } & \multicolumn{3}{|c|}{ Females } & \multicolumn{3}{|c|}{ Total } \\
\hline & & Empl. & Unempl & O.1.f. & Empl. & Unempl. & O.l.f. & Empl. & Unempl. & O.l.f. \\
\hline \multicolumn{11}{|c|}{ Italy } \\
\hline \multirow{3}{*}{$\begin{array}{c}\text { Unempl. } \\
\text { Previously } \\
\text { employed }\end{array}$} & Low & 15.6 & 73.4 & 11.0 & 9.6 & 68.4 & 22.0 & 13.7 & 71.8 & 14.6 \\
\hline & Medium & 19.3 & 69.1 & 11.6 & 11.9 & 70.2 & 17.9 & 16.0 & 69.6 & 14.4 \\
\hline & High & 17.9 & 64.2 & 17.9 & 11.3 & 68.0 & 20.7 & 14.4 & 66.2 & 19.4 \\
\hline \multirow{3}{*}{$\begin{array}{l}\text { Looking for } \\
\text { the first job }\end{array}$} & Low & 4.8 & 85.2 & 9.9 & 4.8 & 80.3 & 14.9 & 4.8 & 82.8 & 12.4 \\
\hline & Medium & 10.2 & 78.9 & 10.9 & 5.4 & 77.9 & 16.7 & 7.7 & 78.4 & 13.9 \\
\hline & High & 12.3 & 66.5 & 21.1 & 5.5 & 71.1 & 23.4 & 8.2 & 69.3 & 22.5 \\
\hline \multirow{3}{*}{$\begin{array}{c}\text { Others } \\
\text { seeking } \\
\text { a job }\end{array}$} & Low & 7.1 & 60.7 & 32.1 & 6.5 & 62.4 & 31.2 & 6.5 & 62.1 & 31.3 \\
\hline & Medium & 7.7 & 56.4 & 35.9 & 5.1 & 61.7 & 33.2 & 5.4 & 61.0 & 33.5 \\
\hline & High & 11.4 & 59.1 & 29.5 & 4.4 & 58.6 & 37.1 & 5.4 & 58.6 & 35.9 \\
\hline \multirow[t]{3}{*}{ Tota 1} & Low & 10.3 & 78.3 & 11.3 & 6.5 & 72.3 & 21.2 & 8.5 & 75.4 & 16.1 \\
\hline & Medium & 14.4 & 72.8 & 12.8 & 7.2 & 70.2 & 22.6 & 10.3 & 71.3 & 18.4 \\
\hline & High & 15.0 & 64.7 & 20.2 & 7.1 & 66.6 & 26.3 & 10.1 & 65.9 & 24.0 \\
\hline \multicolumn{11}{|c|}{ North } \\
\hline \multirow{3}{*}{$\begin{array}{l}\text { Unemployed } \\
\text { total }\end{array}$} & Low & 13.5 & 73.0 & 13.5 & 11.5 & 71.6 & 16.9 & 12.2 & 72.2 & 15.6 \\
\hline & Medium & 24.8 & 57.1 & 18.1 & 12.7 & 65.1 & 22.2 & 16.7 & 62.5 & 20.8 \\
\hline & High & 27.0 & 53.3 & 19.7 & 10.9 & 61.9 & 27.2 & 16.4 & 59.0 & 24.7 \\
\hline \multicolumn{11}{|c|}{ Centre } \\
\hline \multirow{3}{*}{$\begin{array}{l}\text { Unemployed } \\
\text { total }\end{array}$} & Low & 9.7 & 70.8 & 19.4 & 10.5 & 71.4 & 18.1 & 10.2 & 71.2 & 18.6 \\
\hline & Medium & 18.8 & 71.3 & 10.0 & 12.9 & 60.6 & 26.5 & 15.1 & 64.6 & 20.3 \\
\hline & High & 13.1 & 64.3 & 22.6 & 6.3 & 66.7 & 27.0 & 8.6 & 65.8 & 25.5 \\
\hline \multicolumn{11}{|c|}{ South } \\
\hline \multirow{3}{*}{$\begin{array}{l}\text { Unemployed } \\
\text { total }\end{array}$} & Low & 9.9 & 80.1 & 9.9 & 3.8 & 72.7 & 23.5 & 7.3 & 76.9 & 15.8 \\
\hline & Medium & 11.2 & 76.8 & 12.1 & 3.0 & 75.2 & 21.8 & 7.0 & 76.0 & 17.1 \\
\hline & High & 9.6 & 70.6 & 19.8 & 5.0 & 69.6 & 25.5 & 6.8 & 70.0 & 23.2 \\
\hline
\end{tabular}

* Categories for indicator of choosiness: low $=0 \leq C_{i}^{W} \leq 33.3$ percentile; medium $=33.3$ percentile $<C_{i}^{W}<66.7$ percentile; high $=66.7$ percentile $\leq C_{i}^{W} \leq 1$. 
The results for yearly transitions are qualitatively similar to those reported here 28 . Overall, these findings are blurred, and seemingly ambiguous. When searching for a reasonable explanation, it is useful to consider the potential roles of heterogeneity and endogeneity.

For better control of heterogeneity, and still in an exploratory vein, we proceeded to estimate some logit models, with the probability of transition to employment as the dependent variable and a fairly large set of predictors ${ }^{29}$. In addition to the three-level indicator of choosiness, we included personal variables (among which unempleyment duration), household variables, and regional proxies for local labour demand conditions ${ }^{3}$. The summary evidence is that, net of these additional predictors, there is no significant effect of choosiness on the probabilities of transition to employment ${ }^{31}$. By and large, our conclusions remain the same. Choosiness in itself does not appear to have any discernible impact on transition to employment, while it positively affects the probability of leaving the labour force.

From a different perspective, it is sensible - and revealing - to conceive the level of choosiness to be endogenous to the search process. A convincing argument is provided by looking at the evidence above in the light of the theory of job search (see Mortensen, 1986, and Mortensen \& Pissarides, 1999, for reviews), and loosely interpreting the individual indicator of choosiness as an analogue of the reservation wage. Under the assumption that both distribution of the number of offers received per period and wage offer distribution are known to the job-seeker, the level of choosiness is endogenously determined on the basis of the job-seeker's optimal search strategy. In this context, it might well be that differences in the various ingredients end up with highly choosy unemployed people having no lower, and sometimes higher, probabilities of transition to employment than their less choosy counterparts $\frac{32}{\text {. }}$.

\section{Selected results for Italy and concluding comments}

\subsection{Main results}

Some of the main results from the empirical analyses for Italy - 1997.IV, 1998.I and 1998.IV shown in Tables 10-12. The mean indicator of choosiness, together with its standard error $\frac{33}{\text {, }}$ is presented, with a breakdown by:

(a) detailed labour force state and gender;

(b) geographic area, and selected regions;

(c) selected personal and household characteristics: age, education, marital status, household size, number of employed within the household, number of unemployed within the household, woman household head with children by their age.

\footnotetext{
${ }^{28}$ They are available from the authors on request.

${ }^{29}$ Further breakdown of transition matrices was precluded by the modest sample size.

${ }^{30}$ More precisely, the variables - with the number of categories in brackets - were: gender, age (3), education (4), marital status (3), detailed unemployment condition (3), reported duration of search (3), household size (5), number of children within the household (2), number of employed within the household (2), number of other unemployed within the household (2), region (20) or geographic area (4).

${ }^{31}$ Detailed results are available from the authors on request. We again stress their exploratory nature. We did not attempt to control for unobserved heterogeneity. In addition, several predictors are endogenous to the labour market transitions to be explained.

${ }^{32}$ Note, incidentally, that similar findings on the dynamics of search behaviour are not so rare: see, e.g., Micklewright \& Nagy (1999) for evidence from Hungary and Jones \& Riddell (1999) for evidence from Canada. Analogous evidence was found also by Poterba and Summers (1995, p. 214), when analysing the impact of unemployment benefits on labour market transitions in the US: "The reservation wage variable does not exhibit any statistically significant effects on labor market transition probabilities".

${ }^{33}$ The standard error was estimated by the bootstrap (Efron \& Tibshirani, 1993), with 200 replications.
} 
Table 10: Mean indicator of choosiness for groups of job-seekers by detailed labour force state and gender and geographic area:1997.IV, 1998.I and 1998.IV (weighted)

\begin{tabular}{|c|c|c|c|c|c|c|}
\hline \multirow[t]{2}{*}{ Aggregate } & \multicolumn{2}{|c|}{ 1997.IV } & \multicolumn{2}{|c|}{ 1998.I } & \multicolumn{2}{|c|}{ 1998.IV } \\
\hline & Mean & $\begin{array}{l}\text { (Standard } \\
\text { error) }\end{array}$ & Mean & $\begin{array}{l}\text { (Standard } \\
\text { error) }\end{array}$ & Mean & $\begin{array}{l}\text { (Standard } \\
\text { error) }\end{array}$ \\
\hline \multicolumn{7}{|l|}{ Males } \\
\hline Employed & .756 & $(.0071)$ & .752 & $(.0085)$ & .762 & $(.0074)$ \\
\hline Unemployed, previously employed & .536 & $(.0075)$ & .537 & $(.0074)$ & .535 & $(.0083)$ \\
\hline Looking for a first job & .516 & $(.0074)$ & .504 & $(.0075)$ & .498 & $(.0078)$ \\
\hline Others seeking a job & .595 & $(.0198)$ & .614 & $(.0188)$ & .637 & $(.0168)$ \\
\hline Unemployed total & .530 & $(.0051)$ & .526 & $(.0047)$ & .523 & $(.0056)$ \\
\hline Out of labour force & .718 & $(.0277)$ & .685 & $(.0313)$ & .702 & $(.0289)$ \\
\hline Total & .577 & $(.0044)$ & .569 & $(.0042)$ & .572 & $(.0048)$ \\
\hline \multicolumn{7}{|l|}{ Females } \\
\hline Employed & .764 & $(.0075)$ & .750 & $(.0081)$ & .753 & $(.0077)$ \\
\hline Unemployed, previously employed & .594 & $(.0072)$ & .613 & $(.0071)$ & .615 & $(.0069)$ \\
\hline Looking for a first job & .568 & $(.0067)$ & .554 & $(.0077)$ & .566 & $(.0067)$ \\
\hline Others seeking a job & .613 & $(.0069)$ & .621 & $(.0074)$ & .632 & $(.0062)$ \\
\hline Unemployed total & .589 & $(.0037)$ & .592 & $(.0043)$ & .600 & $(.0038)$ \\
\hline Out of labour force & .727 & $(.0251)$ & .697 & $(.0276)$ & .707 & $(.0210)$ \\
\hline Total & .617 & $(.0035)$ & .616 & $(.0037)$ & .627 & $(.0034)$ \\
\hline \multicolumn{7}{|l|}{ Total } \\
\hline Employed & .759 & $(.0051)$ & .751 & $(.0063)$ & .758 & $(.0056)$ \\
\hline Unemployed, previously employed & .561 & $(.0053)$ & .570 & $(.0051)$ & .569 & $(.0212)$ \\
\hline Looking for a first job & .542 & $(.0046)$ & .528 & $(.0054)$ & .532 & $(.0051)$ \\
\hline Others seeking a job & .610 & $(.0070)$ & .620 & $(.0068)$ & .633 & $(.0058)$ \\
\hline Unemployed total & .561 & $(.0031)$ & .560 & $(.0032)$ & .564 & $(.0034)$ \\
\hline Out of labour force & .722 & $(.0181)$ & .692 & $(.0208)$ & .705 & $(.0179)$ \\
\hline Total & .597 & $(.0028)$ & .593 & $(.0027)$ & .601 & $(.0030)$ \\
\hline \multicolumn{7}{|l|}{$\begin{array}{l}\text { Selected regions* and } \\
\text { geographic areas }\end{array}$} \\
\hline Veneto & .726 & $(.0116)$ & .729 & $(.0118)$ & .726 & $(.0108)$ \\
\hline Liguria & .560 & $(.0176)$ & .570 & $(.0159)$ & .602 & (.0169) \\
\hline North & .670 & $(.0048)$ & .659 & $(.0048)$ & .691 & $(.0050)$ \\
\hline Marche & .697 & $(.0165)$ & .737 & $(.0169)$ & .696 & $(.0176)$ \\
\hline Umbria & .587 & $(.0208)$ & .573 & $(.0236)$ & .591 & $(.0206)$ \\
\hline Centre & .611 & $(.0068)$ & .620 & $(.0065)$ & .596 & $(.0069)$ \\
\hline Abruzzo & .630 & $(.0220)$ & .634 & $(.0200)$ & .642 & $(.0177)$ \\
\hline Campania & .538 & (.0079) & .520 & (.0079) & .515 & $(.0080)$ \\
\hline South & .552 & $(.0039)$ & .548 & $(.0038)$ & .554 & $(.0042)$ \\
\hline
\end{tabular}

* Within each geographic area, the two regions with the lower and higher mean indicators respectively are included. 
When examining Tables 10 and 12, it should be recalled that our control for heterogeneity is mild: we are conditioning on a single variable at a time, except for the conditional distribution jointly by labour force state and gender. However, broadly speaking, it is fair to say that our results fit predictions by economic theory. The mean indicator of choosiness varies consistently with expectations across the labour force state and demographic characteristics of job-seekers, as well as across regions characterized by different labour market conditions. Our results are also quite informative, because those differences are appreciable, statistically significant. We draw attention to a few selected findings.

Employed job-seekers are much more choosy than the unemployed ones (.76 vs. .56). The indicator of choosiness of job-seekers out of the labour force is relatively high, not far from that of the employed. Among the unemployed, people looking for a first job are definitely less choosy than job losers (and others seeking a job). Interestingly enough, this pattern is found both within men and women, and constantly across the three survey occasions.

After controlling for labour force state, differences by gender are minor. The only noticeable evidence is among the unemployed. Unemployed women are more choosy than men: in total and within every single unemployment condition.

Regional differences are apparent, and are inversely associated with the unemployment rate 34 . The summary indicator is around .67 in the North (with a peak of .73 in the Veneto region) and around .55 in the South (down to .52 in the Naples region, Campania). Clearly, a composition effect is at work here, the unemployed - particularly people looking for a first job - being a larger fraction of job-seekers in less developed areas. To control for composition effects, we computed standardized regional indicators of choosiness. Standardization - i.e., re-weighting relative to a target population - was done by using as target population the Italian population distributed by gender, age group and detailed labour force state. Results are shown in Table 11, and should be compared with the corresponding, unstandardized indicators of choosiness shown in Table 12. The adjustments operated by standardization are as expected: for the North of Italy, the indicator of choosiness falls by .02-.03, whereas for the South it rises up by .02 (for the Naples region, up by about .03).

Table 11: Standardized mean indicator of choosiness by geographic area (target population Italy, jointly by gender, age group and detailed labour force state):1997.IV, 1998.I and 1998.I

\begin{tabular}{lccc}
\hline \multicolumn{1}{c}{ Selected regions* and geographic areas } & $1997 . \mathrm{IV}$ & $1998 . \mathrm{I}$ & $1998 . \mathrm{IV}$ \\
\hline Veneto & 0.702 & 0.699 & 0.685 \\
Liguria & 0.569 & 0.565 & 0.611 \\
North & 0.647 & 0.631 & 0.665 \\
Marche & 0.704 & 0.738 & 0.693 \\
Umbria & 0.592 & 0.567 & 0.605 \\
Centre & 0.609 & 0.616 & 0.591 \\
Abruzzo & 0.630 & 0.636 & 0.640 \\
Campania & 0.563 & 0.543 & 0.546 \\
South & 0.569 & 0.566 & 0.574 \\
\hline
\end{tabular}

* Within each geographic area, the two regions with the lower and higher mean indicators respectively are included.

\footnotetext{
${ }^{34}$ In 1997.IV, the unemployment rate was $6.4 \%$ in the North, 9.6 in the Centre and 21.5 in the South. It stayed quite stable over the subsequent year.
} 
Table 12: Mean indicator of choosiness for groups of job-seekers by selected personal and household characteristics:1997.IV, 1998.I and 1998.IV (weighted)

\begin{tabular}{|c|c|c|c|c|c|c|}
\hline \multirow[t]{2}{*}{ Personal and household characteristics } & \multicolumn{2}{|c|}{ 1997.IV } & \multicolumn{2}{|c|}{ 1998.I } & \multicolumn{2}{|c|}{ 1998.IV } \\
\hline & Mean & $\begin{array}{c}\text { (Standard } \\
\text { error) }\end{array}$ & Mean & $\begin{array}{c}\text { (Standard } \\
\text { error) }\end{array}$ & Mean & $\begin{array}{c}\text { (Standard } \\
\text { error) }\end{array}$ \\
\hline \multicolumn{7}{|l|}{ Age } \\
\hline $15-29$ & .592 & $(.0036)$ & .584 & $(.0042)$ & .597 & $(.0037)$ \\
\hline $30-54$ & .611 & $(.0045)$ & .612 & $(.0043$ & .616 & $(.0045)$ \\
\hline 55 or more & .520 & $(.0175)$ & .512 & $(.0172)$ & .499 & $(.0194)$ \\
\hline \multicolumn{7}{|l|}{ Education } \\
\hline Elementary ( 5 years) or less & .547 & $(.0085)$ & .534 & $(.0083)$ & .544 & $(.0089)$ \\
\hline Compulsory (8 years) & .576 & $(.0048)$ & .577 & $(.0045)$ & .575 & $(.0045)$ \\
\hline Upper secondary (11-13 years) & .618 & $(.0044)$ & .614 & $(.0045)$ & .627 & $(.0040)$ \\
\hline University degree & .680 & $(.0099)$ & .665 & $(.0099)$ & .681 & $(.0095)$ \\
\hline \multicolumn{7}{|l|}{ Marital status } \\
\hline Unmarried & .591 & $(.0036)$ & .580 & $(.0037)$ & .592 & $(.0038)$ \\
\hline Married & .611 & $(.0047)$ & .617 & $(.0046)$ & .617 & $(.0051)$ \\
\hline Separated, divorced or widow(er) & .586 & $(.0154)$ & .568 & $(.0164)$ & .610 & $(.0139)$ \\
\hline \multicolumn{7}{|l|}{ Household size } \\
\hline 1 & .603 & $(.0152)$ & .606 & $(.0166)$ & .628 & $(.0156)$ \\
\hline 2 & .606 & $(.0086)$ & .599 & $(.0098)$ & .635 & $(.0077)$ \\
\hline 3 & .613 & $(.0057)$ & .601 & $(.0055)$ & .613 & $(.0053)$ \\
\hline 4 & .598 & $(.0050)$ & .603 & $(.0052)$ & .597 & $(.0046)$ \\
\hline 5 or more & .568 & $(.0071)$ & .560 & $(.0075)$ & .568 & $(.0064)$ \\
\hline
\end{tabular}

Number of employed within the household

$\begin{array}{lllllll}\text { None } & .536 & (.0055) & .535 & (.0056) & .535 & (.0051) \\ 1 & .609 & (.0041) & .600 & (.0042) & .610 & (.0044) \\ 2 & .646 & (.0062) & .643 & (.0070) & .655 & (.0061) \\ 3 \text { or more } & .692 & (.0113) & .695 & (.0127) & .692 & (.0110)\end{array}$

Number of unemployed within the household

\begin{tabular}{lllllll} 
None & .765 & $(.0064)$ & .753 & $(.0062)$ & .765 & $(.0056)$ \\
1 & .587 & $(.0037)$ & .584 & $(.0038)$ & .588 & $(.0038)$ \\
2 & .535 & $(.0073)$ & .532 & $(.0069)$ & .539 & $(.0061)$ \\
$\quad 3$ or more & .504 & $(.0116)$ & .513 & $(.0113)$ & .513 & $(.0133)$ \\
\hline $\begin{array}{l}\text { Woman household head with } \\
\text { children }\end{array}$ & & & & & & \\
$\quad$ Aged $<6$ years & & & & & & \\
$\quad$ Aged $\geq 6$ years & .656 & $(.0431)$ & .651 & $(.0450)$ & .687 & $(.0199)$ \\
& .609 & $(.0204)$ & .593 & $(.0181)$ & .621 & $(.0279)$ \\
\hline
\end{tabular}


On the whole, however, adjustments are relatively modest, and do not modify the picture outlined above. Regional differences in choosiness remain quite high. The standardized summary indicator ranges from around .55 for Campania to around .70 for Veneto. Otherwise stated, even after accounting for heterogeneity due to (most of the) composition discrepancies, job-seekers from a relatively well-developed North-Eastern region are still some $30 \%$ more choosy than their counterparts in a less developed region in the South. Essentially, these results point to the importance of local labour demand conditions in influencing both the unemployment rate and the choosiness of the pool of job-seekers.

The distribution of the mean indicator of choosiness by personal and household characteristics of job-seekers is given in Table 12. As already pointed out, it is clearly affected by labour force (and other) composition effect; therefore, it should be interpreted with care. But some evidence still emerges clearly. As regards age, prime age persons are more choosy; by contrast, older job-seekers are less choosy. The ranking of the summary indicator is positively, and markedly, associated with level of education. Household composition, in terms of the number of employed or unemployed household members, entails clear variations in our summary indicator: it ranges from .53 when there is no employed person within the household to .89 when there are at least three persons employed; by contrast, it decreases from .76 to .51 when the number of unemployed persons moves from none to three or more.

\subsection{Opportunities and caveats}

Overall, the exercise of constructing summary indicators of choosiness of the supply of job-seekers seems to be promising, and opens up opportunities in various directions.

The indicator of choosiness at the individual level is of some interest in itself. The empirical evidence for Italy points to a fairly clear-cut polarization of job-seekers into two groups: those (relatively) highly choosy and those poorly choosy. The implications for the labour market (dis)equilibrium process and for labour policies are, arguably, far from negligible. Besides, the individual indicator of choosiness may serve as a synthetic explanatory variable in job search models, when a variable reliably measuring the reservation wage is lacking.

The aggregate (mean) indicator of choosiness may be used for comparisons across groups and over time, possibly by producing an appropriate index number. The results presented above for Italy exemplify some of these uses. Conversely, some caveats are in order. Apart from the usual warnings about using a 'statistical' index number (e.g., problems in choosing and updating the base year), we should take into account for the fact that the number of unemployed varies from one survey occasion to another, and is affected by the well-known pro-cyclical behaviour of labour supply. The mean indicator provides us with a summary measure of the degree of choosiness of the set of persons currently unemployed (or, broadly, seeking a job). Thus, variations in the indicator over time will reflect the combined effect of changes both in choosiness itself - as they are captured by variations in responses to job search questions - and in the size and composition of the pool of unemployed (or, broadly, job-seekers).

Appropriately, the mean indicator is useful for spatial comparisons, although some assumptions must hold - and should be checked preliminarily. Basically, the measurement properties of the indicator should be more or less invariant across space. Now, typically measurement properties depend on measurement instruments - the survey questions and how the questionnaire is administered - and on their perception by respondents - their cultural milieu. If this perception varies greatly, as may be the case across countries, it would be improper to use the indicator of choosiness strictly for cross-country comparisons. Rather, we should content ourselves with comparing, by appropriate index numbers, temporal variations in the indicator of choosiness across countries. 


\section{References}

Agresti A. (1990), Categorical data analysis, New York: Wiley.

Bateman I. and K. Wallis (1995), Valuing environmental preferences: theory and practice of the contingent evaluation method, Oxford: Oxford University Press.

Bertola G., J.F. Jimeno, R. Marimon and C. Pissarides (2000), "Welfare systems and labour market in Europe: what convergence before and after the EMU?", in G. Bertola, T. Boeri, G. Nicoletti (Eds.), Welfare and Employment in a United Europe, Cambridge (Mass.), The MIT Press.

Boeri T. and P. Garibaldi (2000), "Shadow activity and unemployment in a depressed labour market", in IGIER and Fondazione Rodolfo De Benedetti, Le nuove frontiere della politica economica 2000. Dimensioni del lavoro e del non lavoro nel Mezzogiorno d'Italia, Proceedings of Seminar held at Ministero del Tesoro, del Bilancio e della Programmazione Economica, Rome, 19 September 2000 (mimeo).

Böheim R. and M.P. Taylor (2001), "Job Search Methods, Intensity and Success in Britain in the 1990s", ISER Working Papers No. 7-2001, Colchester: University of Essex.

Bound J., C. Brown and N. Mathowetz (2001), "Measurement error in survey data", in J.J. Heckman and D. Leamer (Eds.), Handbook of Econometrics. Volume 5, Amsterdam: North Holland, pp. 3705-3843.

Efron B. and R.J. Tibshirani (1993), An Introduction to the Bootstrap, New York: Chapman \& Hall,

Fleiss J.L., J. Cohen and B.S. Everitt (1969), "Large-sample standard errors of Kappa and Weighted Kappa", Psychological Bulletin, 72, pp. 323-327.

Flinn C.J. and J.J. Heckman (1983), "Are unemployment and out of the labor force behaviorally distinct labor force states?", Journal of Labor Economics, 1, pp. 28-42.

Greenacre M. and J. Blasius (Eds.) (1994), Correspondence analysis in the social sciences. Recent developments and applications, San Diego: Academic Press.

Grubb D. and W. Wells (1993), "Employment regulation and patterns of work in EC Countries", OECD Economic Studies, 21 (Winter), pp. 7-58.

Hausman J. (Ed.) (1993), Contingent valuation: a critical assessment, Amsterdam: North Holland.

Hussmans R., F. Merhan and V. Verma (1990), Surveys of economically active populations, employment, unemployment and underemployment. An ILO manual on concepts and measures, Geneva: International Labour Office.

ILO (1980), “A building block approach for international comparisons of employment and unemployment statistics”, Geneva: International Labour Office (mimeo).

ILO (1983), "Resolution concerning statistics of the economically active populations, employment, unemployment and underemployment”, Bulletin of Labour Statistics, No. 3, pp. xi-xvi.

Jones S.R.G. and W.C. Riddell (1999), "The measurement of unemployment: an empirical approach", Econometrica. 67, pp. 147-162.

Lebart L., A. Morineau and K.M. Warwick (1984), Multivariate descriptive statistical analysis. Correspondence analysis and related techniques for large matrices, New York: Wiley.

Malinvaud E. (1986), Sur les statistiques de l'emploi et du chômage, Paris: La Documentation Française.

Mazzotta F. (1998), "Salario di riserva e probabilità di successo della ricerca di lavoro in Italia: una stima sul nuovo panel Istat”, Lavoro e Relazioni Industriali, 2, pp. 115-173.

Micklewright J. and G. Nagy (1999), "The informational value of job search data and the dynamics of search behaviour: evidence from Hungary", CEPR Discussion Paper No. 2063, London: Centre for Economic Policy Research.

Mortensen D.T. (1986), "Job search and labor market analysis", in O.C. Ashenfelter and R. Layard (Eds.), Handbook of Labor Economics, Volume 2, Amsterdam: Elsevier, pp. 849-919. 
Mortensen D.T. and C.A. Pissarides (1999), "New developments in models of search in the labor market", in O.C. Ashenfelter and D. Card (Eds.), Handbook of Labor Economics, Volume 3B, Amsterdam: Elsevier, pp. 2567-2627.

Nicoletti G., S. Scarpetta and O. Boylaud (1999), "Summary indicators of product market regulation with an extension to employment protection legislation", OECD Economics Department Working paper No. 226, Paris: OECD.

OECD (1994), The OECD Jobs Study. Evidence and explanations. Part II, Paris: OECD.

Osberg L. (1993), "Fishing in different pools: job-search strategies and job-finding success in Canada in the early 1980s", Journal of Labor Economics, 11, pp. 348-386.

Paggiaro A. e N. Torelli (2000), "Una procedura per l'abbinamento di record nella rilevazione trimestrale delle forze di lavoro", Progetto MIUR 'Lavoro e disoccupazione: questioni di misura e di analisi', Working paper n. 15, Padova: Dipartimento di Scienze Statistiche, Università di Padova.

Poterba J.M and L.H. Summers (1995), "Unemployment benefits and labor market transitions: A multinomial logit model with errors in classification", The Review of Economic and Statistics, 77 (2), pp. 207-216:

Rossi F. (1997), "Disoccupazione, offerta di lavoro e lavoro sommerso", in S. De Nardis e G. Galli (Eds.), La disoccupazione italiana. Rapporto del Centro studi Confindustria, Bologna: Il Mulino, pp. 31-89.

Shiskin J. (1976), “Employment and unemployment: the doughnut or the hole?”, Monthly Labor Review, 99 (2), pp. 3-10.

Sorrentino C. (2000), "International unemployment rates: how comparable are they?", Monthly Labor Review, 123 (6), pp. 3-20.

Trivellato U. (1997), "Le misure della partecipazione al lavoro nel quadro comunitario", in L. Frey (Ed.), Le informazioni sul lavoro in Italia: significato e limiti delle informazioni provenienti da indagini sulle famiglie, Quaderni di Economia del Lavoro/59, Milano: Franco Angeli, pp. 9-34. 


\title{
CESifo Working Paper Series
}

\author{
(for full list see www.cesifo.de)
}

860 Haizhou Huang, Dalia Marin, and Chenggang Xu, Financial Crisis, Economic Recovery and Banking Development in Former Soviet Union Economies, February 2003

861 Pedro Cardoso and Bernard M.S. van Praag, How Sustainable Are Old-age Pensions in a Shrinking Population with Endogenous Labour Supply?, February 2003

862 Volker Meier, Efficient Transfer of Aging Provisions in Private Health Insurance, February 2003

863 Edward Castronova, Theory of the Avatar, February 2003

864 Robert S. Chirinko, Hans van Ees, Harry Garretsen, and Elmer Sterken, Investor Protections and Concentrated Ownership: Assessing Corporate Control Mechanisms in the Netherlands, February 2003

865 Bernard M.S. van Praag and Pedro Cardoso, The Mix Between Pay-as-you-go and Funded Pensions and what Demography has to do with it, February 2003

866 Ernst Fehr, Urs Fischbacher, Bernhard von Rosenbladt, Jürgen Schupp, and Gert G. Wagner, A Nation-Wide Laboratory. Examining Trust and Trustworthiness by Integrating Behavioral Experiments into Representative Survey, February 2003

867 Frank Heinemann, The Inflationary Impact of Wage Indexation, February 2003

868 Eytan Sheshinski, Bounded Rationality and Socially Optimal Limits on Choice in a Self-Selection Model, February 2003

869 M. Hashem Pesaran, Estimation and Inference in Large Heterogenous Panels with Cross Section Dependence, February 2003

870 Luis H. R. Alvarez and Erkki Koskela, On the Tree-Cutting Problem under Interest Rate and Forest Value Uncertainty, February 2003

871 Norbert Berthold and Rainer Fehn, Unemployment in Germany: Reasons and Remedies, February 2003

872 Clemens Fuest, Bernd Huber, and Philipp Tilleßen, Tax Policy and Entrepreneurship in the Presence of Asymmetric Information in Capital Markets, February 2003

873 Eytan Sheshinski, Optimum and Risk-Class Pricing of Annuities, February 2003

874 Willi Leibfritz, Paul O'Brien and Jean-Christophe Dumont, Effects of Immigration on Labour Markets and Government Budgets - An Overview, February 2003 
875 M. Hashem Pesaran and Allan Timmermann, How Costly is it to Ignore Breaks when Forecasting the Direction of a Time Series?, February 2003

876 Thorvaldur Gylfason and Gylfi Zoega, Education, Social Equality and Economic Growth: A View of the Landscape, February 2003

877 Robin Boadway and Jean-François Tremblay, Public Economics and Startup Entrepreneurs, February 2003

878 Erkki Koskela and Roope Uusitalo, The Un-Intended Convergence: How the Finnish Unemployment Reached the European Level, February 2003

879 Robert Fenge and Volker Meier, Pensions and Fertility Incentives, February 2003

880 Eytan Sheshinski, Note on Income Taxation and Occupational Choice, February 2003

881 A B Atkinson, Income Inequality in OECD Countries: Data and Explanations, February 2003

882 Thomas Gehrig and Rune Stenbacka, Venture Cycles: Theory and Evidence, February 2003

883 Ralf Becker and Thomas Hellmann, The Genesis of Venture Capital - Lessons from the German Experience, March 2003

884 Eytan Sheshinski, Note on the Optimum Pricing of Annuities, March 2003

885 Paul De Grauwe and Magdalena Polan, Globalisation and Social Spending, March 2003

886 F. van der Ploeg, Do Social Policies Harm Employment and Growth?, March 2003

887 Mirjam van Praag, Initial Capital Constraints Hinder Entrepreneurial Venture Performance: An empirical analysis, March 2003

888 Bernard Steunenberg, Coordinating Sectoral Policymaking: Searching for Countervailing Mechanisms in the EU Legislative Process, March 2003

889 Eytan Sheshinski, Optimum Delayed Retirement Credit, March 2003

890 Frederick van der Ploeg, Rolling Back the Public Sector - Differential effects on employment, investment and growth, March 2003

891 Paul De Grauwe and Marc-Alexandre Sénégas, Monetary Policy in EMU when the Transmission is Asymmetric and Uncertain, March 2003

892 Steffen Huck and Kai A. Konrad, Strategic Trade Policy and the Home Bias in Firm Ownership Structure, March 2003

893 Harry Flam, Turkey and the EU: Politics and Economics of Accession, March 2003 
894 Mathias Hoffmann and Ronald MacDonald, A Re-examination of the Link between Real Exchange Rates and Real Interest Rate Differentials, March 2003

895 Badi H. Baltagi, Espen Bratberg, and Tor Helge Holmås, A Panel Data Study of Physicians' Labor Supply: The Case of Norway, March 2003

896 Dennis C. Mueller, Rights and Citizenship in the European Union, March 2003

897 Jeremy Edwards, Gains from Trade in Tax Revenue and the Efficiency Case for Trade Taxes, March 2003

898 Rainer Fehn and Thomas Fuchs, Capital Market Institutions and Venture Capital: Do They Affect Unemployment and Labour Demand?, March 2003

899 Ronald MacDonald and Cezary Wójcik, Catching Up: The Role of Demand, Supply and Regulated Price Effects on the Real Exchange Rates of Four Accession Countries, March 2003

900 R. Selten, M. Schreckenberg, T. Pitz, T. Chmura, and S. Kube, Experiments and Simulations on Day-to-Day Route Choice-Behaviour, April 2003

901 Stergios Skaperdas, Restraining the Genuine Homo Economicus: Why the Economy Cannot be Divorced from its Governance, April 2003

902 Yin-Wong Cheung, Menzie D. Chinn, and Antonio Garcia Pascual, What Do We Know about Recent Exchange Rate Models? In-Sample Fit and Out-of-Sample Performance Evaluated, April 2003

903 Mika Widgrén, Enlargements and the Principles of Designing EU - Decision-Making Procedures, April 2003

904 Phornchanok Cumperayot, Dusting off the Perception of Risk and Returns in FOREX Markets, April 2003

905 Kai A Konrad, Inverse Campaigning, April 2003

906 Lars P. Feld and Stefan Voigt, Economic Growth and Judicial Independence: Cross Country Evidence Using a New Set of Indicators, April 2003

907 Giuseppe Bertola and Pietro Garibaldi, The Structure and History of Italian Unemployment, April 2003

908 Robert A.J. Dur and Otto H. Swank, Producing and Manipulating Information, April 2003

909 Christian Gollier, Collective Risk-Taking Decisions with Heterogeneous Beliefs, April 2003

910 Alexander F Wagner, Mathias Dufour, and Friedrich Schneider, Satisfaction not Guaranteed - Institutions and Satisfaction with Democracy in Western Europe, April 2003 
911 Ngo Van Long, Raymond Riezman, and Antoine Soubeyran, Trade, Wage Gaps, and Specific Human Capital Accumulation, April 2003

912 Andrea Goldstein, Privatization in Italy 1993-2002: Goals, Institutions, Outcomes, and Outstanding Issues, April 2003

913 Rajshri Jayaraman and Mandar Oak, The Signaling Role of Municipal Currencies in Local Development, April 2003

914 Volker Grossmann, Managerial Job Assignment and Imperfect Competition in Asymmetric Equilibrium, April 2003

915 Christian Gollier and Richard Zeckhauser, Collective Investment Decision Making with Heterogeneous Time Preferences, April 2003

916 Thomas Moutos and William Scarth, Some Macroeconomic Consequences of Basic Income and Employment Subsidies, April 2003

917 Jan C. van Ours, Has the Dutch Miracle Come to an End?, April 2003

918 Bertil Holmlund, The Rise and Fall of Swedish Unemployment, April 2003

919 Bernd Huber and Marco Runkel, Optimal Design of Intergovernmental Grants under Asymmetric Information, April 2003

920 Klaus Wälde, Endogenous Business Cycles and Growth, April 2003

921 Ramon Castillo and Stergios Skaperdas, All in the Family or Public? Law and Appropriative Costs as Determinants of Ownership Structure, April 2003

922 Peter Fredriksson and Bertil Holmlund, Improving Incentives in Unemployment Insurance: A Review of Recent Research, April 2003

923 Bernard M.S. van Praag and Adam S. Booij, Risk Aversion and the Subjective Time Discount Rate: A Joint Approach, April 2003

924 Yin-Wong Cheung, Dissecting the PPP Puzzle: The Unconventional Roles of Nominal Exchange Rate and Price Adjustment, April 2003

925 Ugo Trivellato and Anna Giraldo, Assessing the 'Choosiness' of Job Seekers. An Exploratory Approach and Evidence for Italy, April 2003 